\title{
Modeling Water Quality, Temperature, and Flow in Link River, South-Central Oregon
}

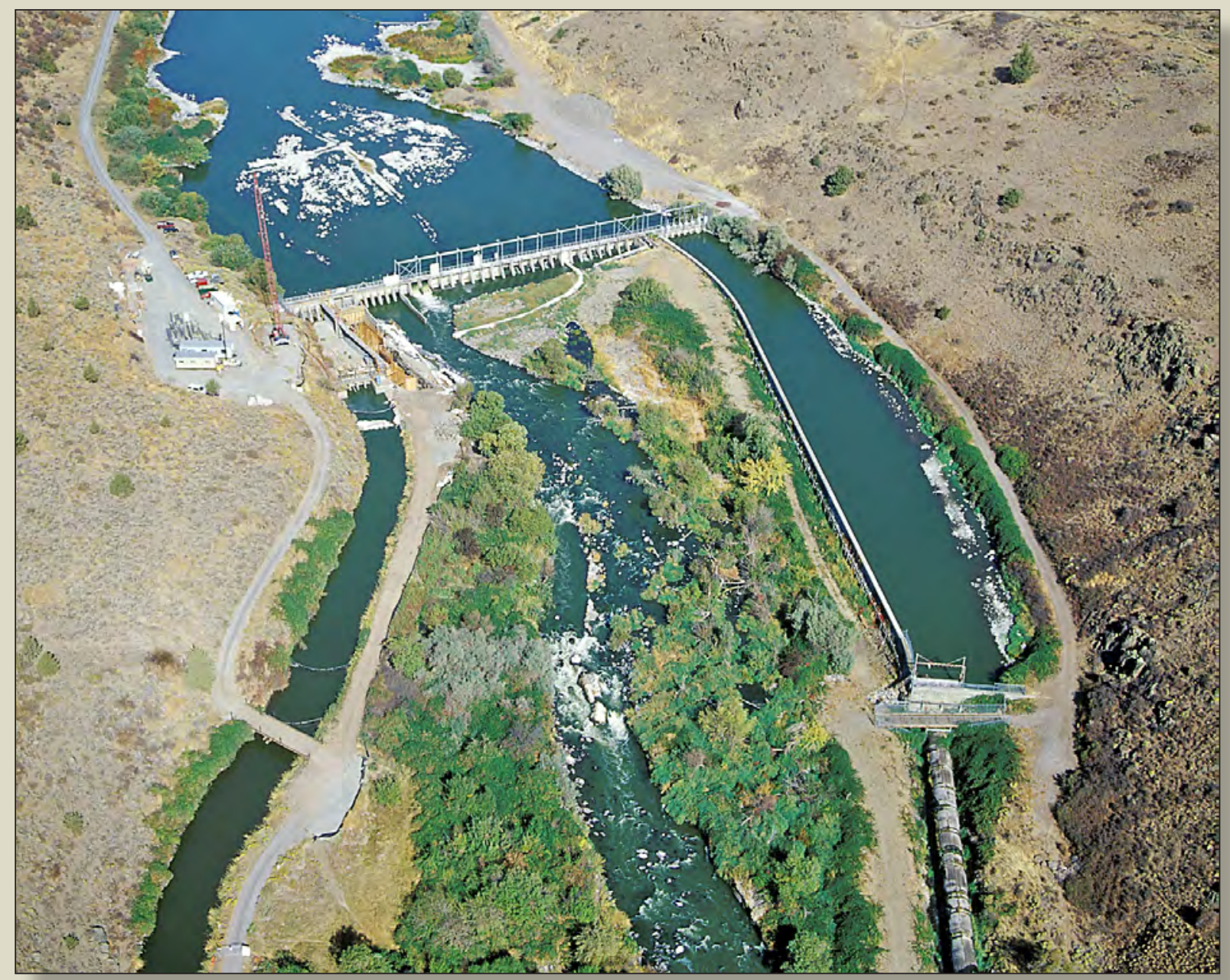

Open-File Report 2016-1146 


\section{Covers:}

Front: Photograph showing aerial view of Link River Dam, Oregon, 2000.

Back: Photograph showing Link River looking downstream from Link River Dam, Oregon, 2015.

Photographs courtesy of Bureau of Reclamation. 


\section{Modeling Water Quality, Temperature, and Flow in Link River, South-Central Oregon}

By Annett B. Sullivan and Stewart A. Rounds

Prepared in cooperation with the Bureau of Reclamation

Open-File Report 2016-1146

U.S. Department of the Interior

U.S. Geological Survey 


\section{U.S. Department of the Interior \\ SALLY JEWELL, Secretary}

\section{U.S. Geological Survey \\ Suzette M. Kimball, Director}

U.S. Geological Survey, Reston, Virginia: 2016

For more information on the USGS—-the Federal source for science about the Earth, its natural and living resources, natural hazards, and the environment-visit http://www.usgs.gov/ or call 1-888-ASK-USGS (1-888-275-8747).

For an overview of USGS information products, including maps, imagery, and publications, visit http://store.usgs.gov.

Any use of trade, firm, or product names is for descriptive purposes only and does not imply endorsement by the U.S. Government.

Although this information product, for the most part, is in the public domain, it also may contain copyrighted materials as noted in the text. Permission to reproduce copyrighted items must be secured from the copyright owner.

\section{Suggested citation:}

Sullivan, A.B., and Rounds, S.A., 2016, Modeling water quality, temperature, and flow in Link River, south-central Oregon: U.S. Geological Survey Open-File Report 2016-1146, 31 p., http://dx.doi.org/10.3133/ofr20161146.

ISSN 2331-1258 (online) 


\section{Contents}

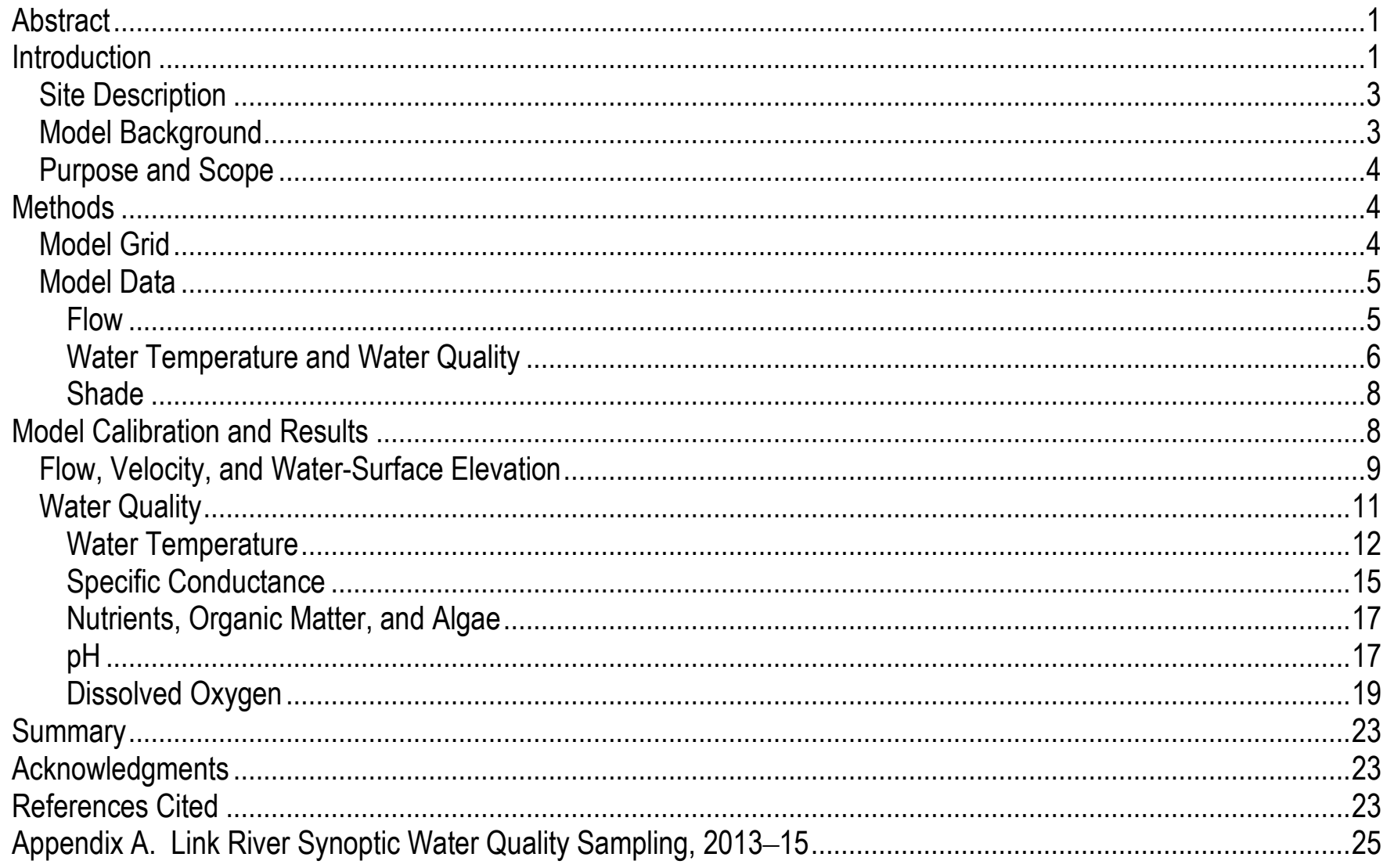




\section{Figures}

Figure 1. Map showing Link River and sampling site locations, south-central Oregon

Figure 2. Graphs showing water temperature, $\mathrm{pH}$, specific conductance, dissolved oxygen, and sensor

depth for sondes at Link River Dam and Link River Bridge, south-central Oregon, 2006-1.

Figure 3. Graphs showing simulated and measured Link River flow at USGS streamgage 11507500 , south-central Oregon, 2006-09 and 2011.

Figure 4. Graphs showing simulated and measured Link River water-surface elevation at USGS streamgage 11507500, south-central Oregon, 2006-09 and 2011

Figure 5. Graphs showing simulated water velocity along Link River, south-central Oregon, for selected days in 2008 .

Figure 6. Graphs showing simulated and measured water temperature near mouth of Link River (site 11507501), south-central Oregon, 2006-09 and 2011.

Figure 7. Graphs showing simulated and measured specific conductance near mouth of Link River (site 11507501), south-central Oregon, 2006-09 and 2011.

Figure 8. Graphs showing simulated and measured pH near mouth of Link River (site 11507501), south-central Oregon, 2006-09 and 2011

Figure 9. Graphs showing simulated and measured dissolved oxygen near mouth of Link River (site 11507501), south-central Oregon, 2006-09 and 2011.

Figure 10. Graphs showing simulated and measured dissolved oxygen saturation near mouth of Link River (site 11507501), south-central Oregon, 2006-09 and 2011.

Figure 11. Graphs showing simulated dissolved oxygen saturation along Link River, south-central Oregon, for selected days in 2008 .

\section{Tables}

Table 1. Differences in various hydrodynamic and water-quality model parameters for the Link River and Keno models 12

Table 2. Goodness-of-fit statistics for hourly water-quality results at the outflow of the Link River model to the Link-Keno boundary input file at the same location, which was derived from measured values. 


\section{Conversion Factors}

Inch/Pound to International System of Units

\begin{tabular}{lcl}
\hline & Multiply & \\
\hline & Length & To obtain \\
\hline foot $(\mathrm{ft})$ & 0.3048 & meter $(\mathrm{m})$ \\
mile $(\mathrm{mi})$ & 1.609 & kilometer $(\mathrm{km})$ \\
\hline & Area & \\
\hline acre & 0.047 & hectare $(\mathrm{ha})$ \\
acre & 0.004047 & square kilometer $\left(\mathrm{km}^{2}\right)$ \\
\hline & Flow rate & \\
\hline foot per second $(\mathrm{ft} / \mathrm{s})$ & 0.3048 & meter per second $(\mathrm{m} / \mathrm{s})$ \\
cubic foot per second $\left(\mathrm{ft}^{3} / \mathrm{s}\right)$ & 0.02832 & cubic meter per second $\left(\mathrm{m}^{3} / \mathrm{s}\right)$ \\
\hline
\end{tabular}

International System of Units to Inch/Pound

\begin{tabular}{lcl}
\hline & Multiply & \\
\hline & Length & \\
\hline micrometer $(\mu \mathrm{m})$ & 0.0000394 & inch (in) \\
meter $(\mathrm{m})$ & 3.281 & foot $(\mathrm{ft})$ \\
kilometer $(\mathrm{km})$ & 0.6214 & mile $(\mathrm{mi})$ \\
\hline & Flow rate & \\
\hline meter per second $(\mathrm{m} / \mathrm{s})$ & 3.28084 & foot per second $(\mathrm{ft} / \mathrm{s})$ \\
cubic meter per second $\left(\mathrm{m}^{3} / \mathrm{s}\right)$ & 70.07 & acre-foot per day $(\mathrm{acre}-\mathrm{ft} / \mathrm{d})$ \\
\hline
\end{tabular}

Temperature in degrees Celsius $\left({ }^{\circ} \mathrm{C}\right)$ may be converted to degrees Fahrenheit $\left({ }^{\circ} \mathrm{F}\right)$ as ${ }^{\circ} \mathrm{F}=\left(1.8 \times{ }^{\circ} \mathrm{C}\right)+32$.

\section{Datums}

Vertical coordinate information is referenced to the Upper Klamath Lake Vertical Datum (UKLVD), established by the Bureau of Reclamation. For this report, the conversion is UKLVD - $1.78 \mathrm{ft}=$ National Geodetic Vertical Datum of 1929 (NGVD29).

Horizontal coordinate information is referenced to the [insert datum name (and abbreviation) here for example, North American Datum of 1983 (NAD 83)].

Elevation as used in this report, refers to distance. 


\section{Supplemental Information}

Specific conductance is given in microsiemens per centimeter at 25 degrees Celsius $\left(\mu \mathrm{S} / \mathrm{cm}\right.$ at $\left.25^{\circ} \mathrm{C}\right)$.

Concentrations of chemical constituents in water are given in either milligrams per liter ( $\mathrm{mg} / \mathrm{L})$ or micrograms per liter $(\mu \mathrm{g} / \mathrm{L})$.

\section{Abbreviations}

Reclamation
GIS
MAE
ME
NWQL
ODEQ
RMSE
TDS
TMDL
USGS

Bureau of Reclamation

geographic information system

mean absolute error

mean error

National Water Quality Laboratory

Oregon Department of Environmental Quality

root mean square error

total dissolved solids

Total Maximum Daily Load

U.S. Geological Survey 


\title{
Modeling Water Quality, Temperature, and Flow in Link River, South-Central Oregon
}

\author{
By Annett B. Sullivan and Stewart A. Rounds
}

\section{Abstract}

The 2.1-km (1.3-mi) Link River connects Upper Klamath Lake to the Klamath River in southcentral Oregon. A CE-QUAL-W2 flow and water-quality model of Link River was developed to provide a connection between an existing model of the upper Klamath River and any existing or future models of Upper Klamath Lake. Water-quality sampling at six locations in Link River was done during 2013-15 to support model development and to provide a better understanding of instream biogeochemical processes. The short reach and high velocities in Link River resulted in fast travel times and limited water-quality transformations, except for dissolved oxygen. Reaeration through the reach, especially at the falls in Link River, was particularly important in moderating dissolved oxygen concentrations that at times entered the reach at Link River Dam with marked supersaturation or subsaturation. This reaeration resulted in concentrations closer to saturation downstream at the mouth of Link River.

\section{Introduction}

Link River connects Upper Klamath Lake to the Klamath River in south-central Oregon (fig. 1). A CE-QUAL-W2 water quality, temperature, and flow model of Link River was constructed in this study for years 2006-09 and 2011 to connect to an existing Klamath River model (Sullivan and others, 2011, 2013), and eventually tie to Upper Klamath Lake models. A Link River model would allow the entire reach from Upper Klamath Lake to the upper Klamath River to be modeled and allow the examination and testing of the water-quality effects of various management strategies. Modeling needs for the Upper Klamath area include those related to Total Maximum Daily Load (TMDL) and Endangered Species Act requirements, climate change, irrigation/water-use activities, and restoration, among others. Water-quality sampling along Link River was done as part of this study during 2013-15 to improve understanding of water-quality patterns and processes. This project was done in cooperation with Bureau of Reclamation (Reclamation). 


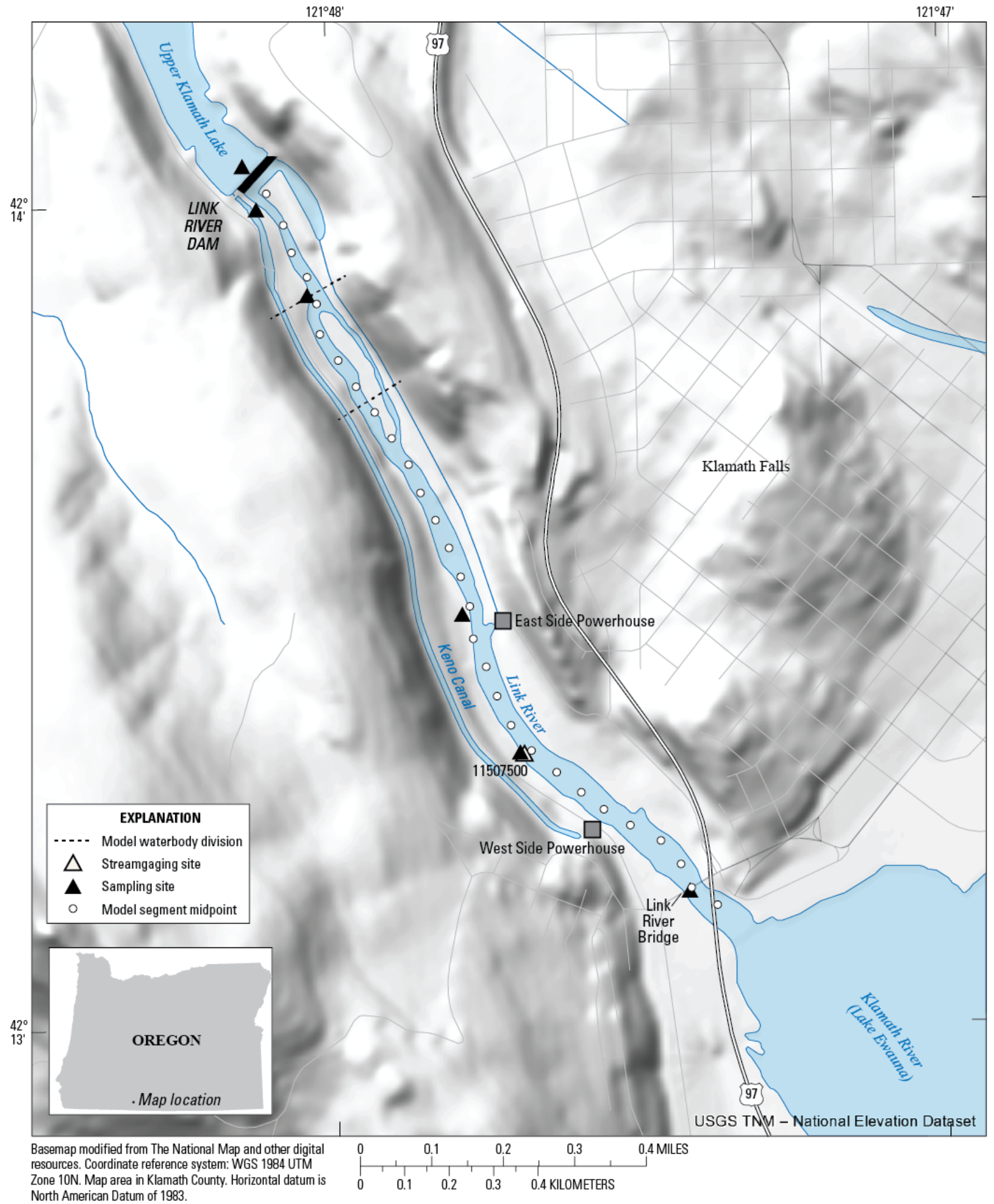

Figure 1. Map showing Link River and sampling site locations, south-central Oregon. 


\section{Site Description}

Link River Dam marks the upstream boundary of the modeled Link River reach. The dam, completed in 1921, was constructed to control water levels in Upper Klamath Lake and develop usable storage for beneficial uses. The dam elevation ranges from 1,263 m (4,145 ft) Upper Klamath Lake Vertical Datum [UKLVD]) at the top to $1,259 \mathrm{~m}(4,130 \mathrm{ft})$ mean sea level $(\mathrm{msl})$ at the bottom

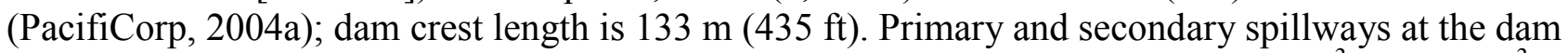
each have multiple gates. Six primary cast iron spill gates can spill as much as $28.3 \mathrm{~m}^{3} / \mathrm{s}\left(1,000 \mathrm{ft}^{3} / \mathrm{s}\right)$, and 25 secondary stoplog spill gates can spill as much as $339.8 \mathrm{~m}^{3} / \mathrm{s}\left(12,000 \mathrm{ft}^{3} / \mathrm{s}\right)$.

For the years modeled in this study, most water from Link River Dam was released downstream into Link River through spill gates and a fish ladder. Some additional water was diverted by intake gates into channels that fed the West Side and East Side hydropower plants. The West Side and East Side hydropower plants were active historically and for parts of the years that were modeled, but currently (2016) are shut down except for some leakage through the East Side flowline, which is made of wood stave construction. PacifiCorp has estimated this leakage as about $2.3-2.8 \mathrm{~m}^{3} / \mathrm{s}\left(80-100 \mathrm{ft}^{3} / \mathrm{s}\right)$.

The river cascades over bedrock and alluvial material in the main channel of Link River starting at about $98 \mathrm{~m}(320 \mathrm{ft})$ downstream of Link River Dam (Mefford and Higgs, 2006). These rapids gave the

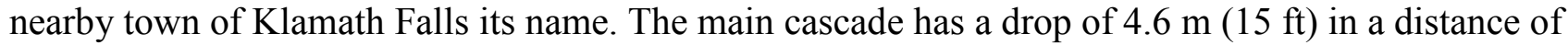
$137 \mathrm{~m}(450 \mathrm{ft})$. Two-thirds of the drop (3 m [10 ft]) occurs in a single $30 \mathrm{~m}(100 \mathrm{ft})$ long cascade. Below the falls, the river flows around a small island and then the river slope decreases in the lower part of Link River. Link River ends at its mouth, where it flows into Lake Ewauna, a wide, lake-like area at the start of the Klamath River that forms the upper part of a 32-km (20-mi) impoundment regulated by Keno Dam. The total vertical drop from Link River Dam to the Klamath River $2.1 \mathrm{~km}$ (1.3 mi) downstream is about $13 \mathrm{~m}(44 \mathrm{ft})$.

The topography and riparian vegetation of the reach affect the heat budget of the river through shading of solar radiation. PacifiCorp completed a survey of vegetation along Link River during 200102 (PacifiCorp, 2004b). The area immediately adjacent to Link River included 19.8 acres classified as Riparian Deciduous habitat, 11.3 acres of Riparian Shrub habitat, and 2.7 acres of Riparian Grassland habitat. The east side of Link River also had areas classified as Developed/Residential and Chaparral. Tree species identified in the survey along Link River included bigleaf maple (Acer macrophyllum Pursh), water birch (Betula occidentalis Hook.), red manjack (Cordia collococca), Oregon ash (Fraxinus latifolia Benth.), melochia (Melochia), arroyo willow (Salix lasiolepis Benth.), shining willow (Salix lucida Muhl.), and narrowleaf willow (Salix exigua Nutt.). The presence of apple (Malus), plum (Prunus), and elm (Ulmus) trees also was noted. The Riparian Shrub habitat was more common in the upstream part of Link River, and the Riparian Deciduous habitat was more common in the lower reach.

\section{Model Background}

The Link River model was developed with CE-QUAL-W2 version 3.6, a two-dimensional (longitudinal, vertical) water-quality, temperature, and flow model (Cole and Wells, 2008). The version used for this work also included improvements to the $\mathrm{pH}$ algorithm (Sullivan and others, 2013). The same version of CE-QUAL-W2 was used previously to develop a model for the Klamath River from the mouth of Link River to Keno Dam. This downstream Klamath River model is designated as the "Keno model" in this report. The Link River model was developed as a separate stand-alone model, instead of as an extension of the existing Keno model. The output from the downstream end of the Link River model becomes the input for the Keno model. 
The rationale for keeping the Link River model separate is that the steep slopes and high velocities in Link River required short time steps for the Link River model to maintain model stability, resulting in long model-simulation times. If a Link River model and Keno model were combined, the shorter time steps of the Link River model would be applied to the entire river-reservoir reach, resulting in extended simulation times. With separate models, a user has the option to only use the faster Keno model and (or) the slower Link River model, as needed. However, certain development decisions for the Link River model were made to facilitate the construction of a combined model in the future, such as specifying a model layer height in the Link River model that is identical to that used in the Keno model.

A Link River model was developed previously with RMA-2 and RMA-11 software to support Federal Energy Regulatory Commission relicensing activities for several PacifiCorp hydroelectric projects (PacifiCorp, 2005). This model was subsequently used in the development of TMDLs for the Klamath River (Tetra Tech, 2009). A flow and velocity model of the upper part of Link River, near the falls, was developed by Mefford and Higgs (2006) for fish passage investigations, but that threedimensional model was not designed for water-quality simulations.

\section{Purpose and Scope}

The rationale for constructing a new Link River model in this study was two-fold. First, this study was designed with specific field work to collect data that would allow for a better understanding of biogeochemical processes occurring in Link River. The time periods modeled with the earlier RMA models did not include certain important pieces of information on nutrients, organic matter, and algae, whereas later datasets that had already been used with the Keno CE-QUAL-W2 model were available and could be modified or augmented. Second, development of a CE-QUAL-W2 model for Link River would allow more seamless integration and information transfer between the Link River and Klamath River models. For instance, RMA treats organic matter as a lumped parameter, whereas CE-QUAL-W2 partitions it into four different components with different properties and decomposition rates.

The Link River model was developed for the 2.1-km (1.3-mi) reach from Link River Dam to the mouth of Link River for calendar years 2006-2009 and 2011. Modeled constituents included flow, velocity, water level, water temperature, nitrogen and phosphorus species, organic matter, dissolved oxygen, $\mathrm{pH}$, and algae. Water-quality sampling for nutrients and other water-quality constituents done along Link River in 2013-15, supported model development and further defined spatial and temporal variations in water quality and temperature in this reach. Existing sonde (multiparameter instrument) data from upstream of Link River Dam and at the mouth of Link River also were analyzed for the years modeled; these data included $\mathrm{pH}$, dissolved oxygen, water temperature, and specific conductance.

\section{Methods}

\section{Model Grid}

The Link River model grid was based on digital bathymetry of Link River provided by the Bureau of Reclamation. To produce the model segments (lengths along the direction of flow) that comprise the model grid, the locations of model segment boundaries were first digitized. Using geographic information system (GIS) tools, 10 intermediate cross sections were sampled between model segment boundaries. These subsections were averaged to obtain representative cross sectional forms for each segment. 
The relatively steep channel margins, shallow water depths, and high water velocities typical of Link River presented some grid construction constraints and challenges. For instance, the model segment length needed to be long enough so that high-velocity water was not conveyed through a segment in one time step, and yet short enough to capture longitudinal variations and minimize numerical dispersion. To represent the cascades where water-surface elevation discontinuities occurred, the reach was divided into three "waterbodies." The first waterbody extended from Link River Dam through the falls in Link River and consisted of four segments with a slope of 0.00651 (dimensionless, or meter per meter or foot per foot). The second waterbody began at the end of the falls and consisted of four segments with a slope of 0.00473 . The third waterbody extended from the end of the second waterbody to the mouth of Link River and consisted of 21 segments and a slope of 0.00801. A 2-m (6.6$\mathrm{ft})$ drop was incorporated between the first and second waterbody to represent the falls in Link River, and a 2-m (6.6-ft) drop was added between the second and third waterbodies to represent another steep, cascading section. CE-QUAL-W2 requires a "structure" at elevation breaks in the model grid, so model spillways were added at those two locations. During model development, minor refinements were made to the raw grid to improve model stability, such as smoothing layer widths between segments. The final Link River grid was composed of 3 waterbodies, 29 active segments with segment lengths between 61 and $76 \mathrm{~m} \mathrm{(200} \mathrm{and} 250 \mathrm{ft})$, and horizontal layers $0.61 \mathrm{~m}(2 \mathrm{ft})$ high.

Link River Dam and its outlet structures were not included in the model or its grid, because of the lack of detailed information to describe the release rates through those structures. Initial model development tested the inclusion of some structures, but inclusion of spillway reaeration for dissolved oxygen offered only marginal improvement of model results, at the high cost of shorter time steps and longer run times. Because of the lack of data and relative insensitivity of model results to the presence of these structures in the model, the dam itself was not included in the model grid.

The end of the Link River grid was set at Link River mouth, at the start of the pooled section of the Klamath River that is regulated by Keno Dam $32 \mathrm{~km}$ (20 mi) downstream. A minor modification was made to the Keno model grid to accommodate a connection/linkage to the Link River model grid where the river meets the pooled section of the Klamath River. Specifically, the upstream end of the first segment boundary of the Keno model was extended upstream by $143.1 \mathrm{~m}(469.5 \mathrm{ft})$ to match the downstream end of the last Link River model segment. The Keno model was run with both the modified and original grids, and results were not significantly different.

\section{Model Data}

\section{Flow}

Upstream boundary flows at Link River Dam were determined by subtracting East Side powerhouse flows from flows at the U.S. Geological Survey (USGS) Link River streamgage 11507500 (fig. 1). The streamgage flows were available at half-hourly intervals, whereas East Side flows were available as daily average data. On days when Link River flow varied substantially, this subtraction of daily average data from half-hourly data could produce negative or extremely low hourly flow estimates for Link River Dam releases for parts of a day. Negative flows were not realistic and extremely low flows were unlikely as well because of instream-flow requirements for Link River. Data on the actual subdaily variation of East Side flows would be ideal, but that information was not available. Thus, to address any unrealistic negative or low flows in Link River, the East Side flow data were decreased for those parts of a day when negative or low Link River Dam release estimates resulted from this subtraction. East Side and West Side powerhouse flows were included in the model as tributary flows at the appropriate model segment. 
The downstream end of the Link River model was constructed as an external head boundary, tied to the water-surface elevation of the first segment of the Keno model. This boundary condition helped to provide a smooth transition between the two models. Flow in the upper reaches of the Link River model was largely unaffected; the external head boundary had its largest effect on velocities near the end of the Link River model. Some extra distributed tributary flow (diffuse inputs of water) was added to the first waterbody of the Link River model during several low-flow periods to improve model stability. These distributed flows ranged from 1 to $6 \mathrm{~m}^{3} / \mathrm{s}\left(35-212 \mathrm{ft}^{3} / \mathrm{s}\right)$ for the following periods: (1) day-of-year 215 , 238, 247 (August 3, 26, September 4) in 2007, (2) day 211 (July 29) in 2008, (3) days 57-66 (February 26-March 7) in 2009, and (4) days 285-293 (October 12-20) in 2011.

\section{Water Temperature and Water Quality}

Prior to constructing the water-quality input file at Link River Dam, existing and newly collected sonde and water-quality data were examined at Link River Dam, Link River mouth, and intermediate sites. Hourly sonde data were available at both Link River Dam and Link River mouth from Reclamation installations. A relatively complete dataset to drive the CE-QUAL-W2 model was available for the modeled years $(2006-2009,2011)$ at the Link River mouth site to support the Keno models. Additional water-quality data collected by PacifiCorp, Reclamation, and Oregon Department of Environmental Quality (ODEQ) in this reach also were available.

Hourly sonde data indicated that water temperature, $\mathrm{pH}$, and specific conductance data differed by only minor amounts between Link River Dam and Link River Bridge (fig. 2) near the mouth of the river. This finding was consistent with data collected during this study (see appendix A). In contrast, dissolved oxygen concentrations and saturation percentage at times indicated large differences between the Link River Dam and Link River mouth locations (fig. 2). The sonde data indicated that dissolved oxygen concentrations at Link River Dam ranged from 40 percent to more than 200 percent of saturation. At Link River Bridge, saturation typically was closer to 100 percent, although at times it ranged from about 50 to 150 percent of saturation. Aeration processes in Link River meant that supersaturated waters could lose dissolved oxygen and undersaturated waters could gain dissolved oxygen. Field data along Link River indicated large changes in dissolved oxygen concentration with distance from Link River Dam, with the largest change occurring at the falls in Link River (fig. A1) because of mechanical reaeration. Some aeration also occurred at Link River Dam when water with low dissolved oxygen entered Link River from Upper Klamath Lake.

The sonde sensors at the Link River Dam and Link River Bridge sites typically were deployed at about $1 \mathrm{~m}(3.3 \mathrm{ft})$ depth during the modeled time periods, with one anomalous period when the sensors at Link River Dam may have been deeper (fig. 2). Ideally, when comparing two sites, data would be collected at similar depths. However, the comparison should be valid if the sites are consistently wellmixed and little vertical stratification occurs. A review of selected historical sonde profile data at those two sites indicated that for typical conditions, vertical stratification was minor. However, this is noted as a source of potential uncertainty in the comparison of the datasets. 

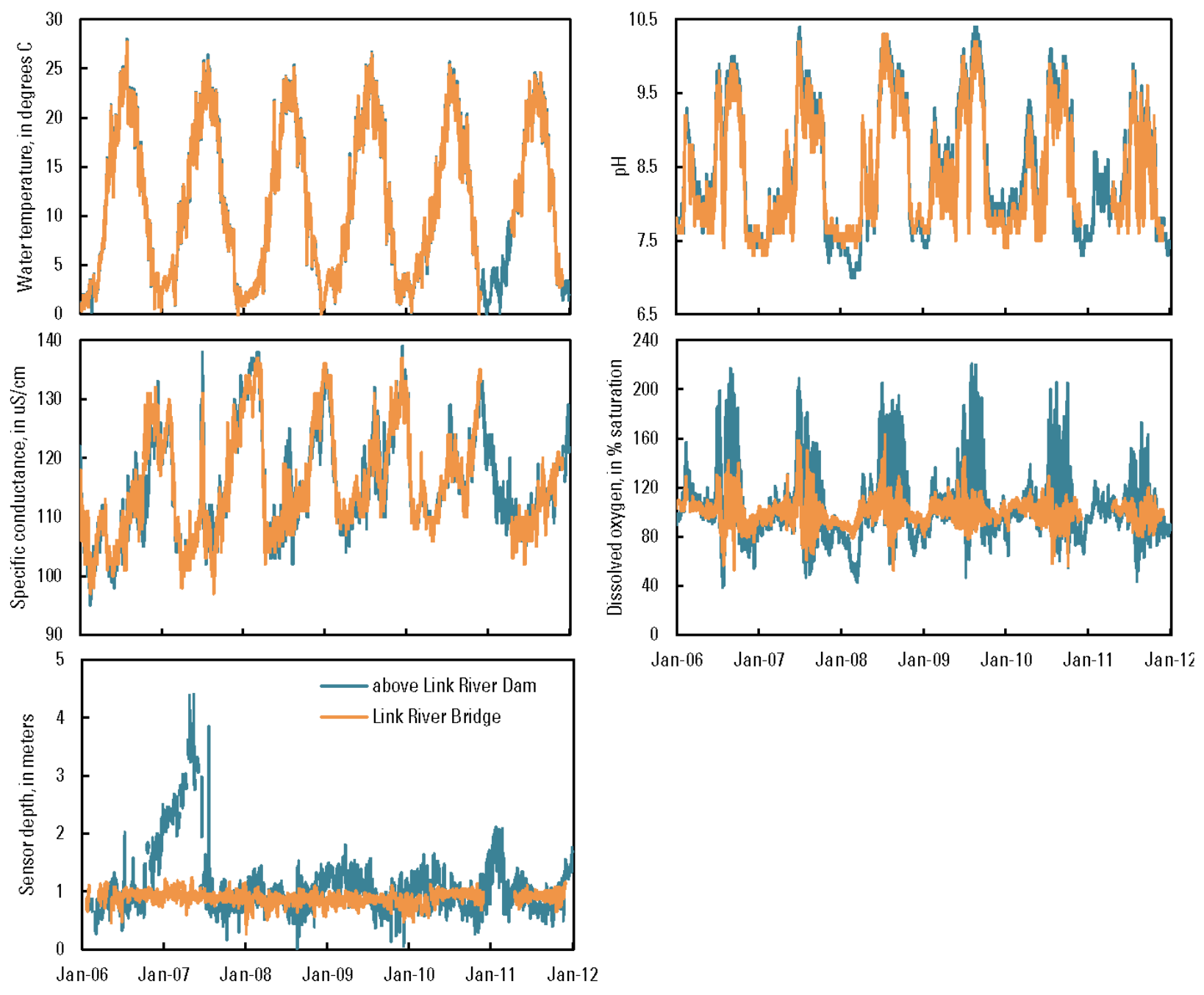

Figure 2. Graphs showing water temperature, $\mathrm{pH}$, specific conductance, dissolved oxygen, and sensor depth for sondes at Link River Dam and Link River Bridge, south-central Oregon, 2006-11. Abbreviations: C, Celsius; uS/cm, microsiemens per centimeter; \%, percent.

Water samples were collected at six sites along Link River (fig. 1) during 2013-15 to augment the available nutrient and field parameter data, and to help determine the extent to which instream processes affected nutrient concentrations. This field study and the resulting data are documented in appendix A. Most of the recent nutrient (nitrogen and phosphorus) data collected along the length of Link River did not reveal any discernible spatial patterns of concentration change. One exception was dissolved nitrate, which seemed to increase in concentration on several dates in summer, potentially because of releases from algae or decomposing organic matter. However, seasonal patterns in nutrient concentrations typically were much greater than spatial changes over this $2.1-\mathrm{km}(1.3-\mathrm{mile})$ distance. In 2013 and 2014, there were several instances of nitrite plus nitrate concentrations greater than $0.3 \mathrm{mg} / \mathrm{L}$ during summer, whereas nitrite plus nitrate concentrations during 2006-09 and 2011 were lower during summer (typically less than $0.1 \mathrm{mg} / \mathrm{L}$ ). 
Following this data review, water-quality boundary conditions were developed with sonde data from Link River Dam and nutrient and organic matter data from Link River mouth. Nutrient and organic matter data were minimal at Link River Dam for the years modeled compared to the large dataset at Link River mouth, and the water-quality transformations in Link River were noted to be minor. Waterquality data were not available for East Side and West Side powerhouse flows, so temperatures and water quality there were assumed to be equal to those assigned at Link River Dam.

\section{Shade}

Riparian and topographic shading can be important influences on water temperature in streams such as Link River, which traverses a tree-lined canyon. CE-QUAL-W2 can account for the effects of topographic and vegetative shade. Topographic shading was potentially significant for some parts of the Link River reach; therefore, topographic shading was included in the Link River model. The topographic shade angles required for the model shade input file were derived from GIS analyses of the controlling topographic inclination angle at 20-degree increments around the center point of each model segment.

Vegetation information required to produce a shade input file includes vegetation height, extent and density, distance from the river centerline to the shade-controlling line of vegetation, and an estimate of the dates of "leaf-out" in spring and "leaf-fall" in autumn for deciduous vegetation; much of this information was derived from PacifiCorp vegetation data (PacifiCorp, 2004b). The vegetation characteristics of the left and right banks of the river are separated in the shade input file. Vegetation along the left and right banks of Link River was designated by PacifiCorp as either Riparian Deciduous or Riparian Shrub habitat. Only the tall woody riparian vegetation (that is, trees) in each category was considered in the CE-QUAL-W2 shade file; the low-height bushes and grasses did not have a substantial shading effect and were not included. The Riparian Deciduous category had average tree heights of 14 $\mathrm{m}(46 \mathrm{ft})$ and average tree coverage of 55 percent, and the Riparian Shrub habitat had average tree heights of $5.8 \mathrm{~m}$ and average tree coverage of 5.3 percent. The tree density was considered as 100 percent of the tree coverage extent, and 50 percent during winter.

\section{Model Calibration and Results}

Calibration of the Link River model proceeded in a stepwise fashion, starting with an examination of the water budget, and then calibration of the flows, water levels, and velocities. After the movement and amount of water through the system was captured adequately, model calibration focused on the heat budget and resulting water temperatures with effects from riparian and topographic shading. Water temperatures are critical because they have an important effect on reaction and growth rates for most of the water-quality constituents. Finally, the ability of the model to simulate water-quality constituents was examined, starting with largely nonreactive constituents such as specific conductance, moving to nutrients and organic matter, and then algae, dissolved oxygen, and $\mathrm{pH}$. 


\section{Flow, Velocity, and Water-Surface Elevation}

Numerous factors determined the flows at Link River Dam, including the need to regulate Upper Klamath Lake levels and provide minimum downstream flows. Flows at Link River Dam in the years modeled typically were largest in spring, especially in a wet water year like 2006 (fig. 3). Flow pulsing at Link River Dam to support a fish passage study (Marine and Lappe, 2009) provided a variable flow pattern in summer 2008. The model simulated the levels and patterns of flow in Link River accurately, largely matching measured flows at the streamgage near the Link River mouth. The modeled watersurface elevations also were close to measured values at that gage, although with somewhat higher than measured values at higher flow (fig. 4). Attempts were made to minimize these errors in the simulated water level at the gage location by widening the layers by a minor amount at this location.
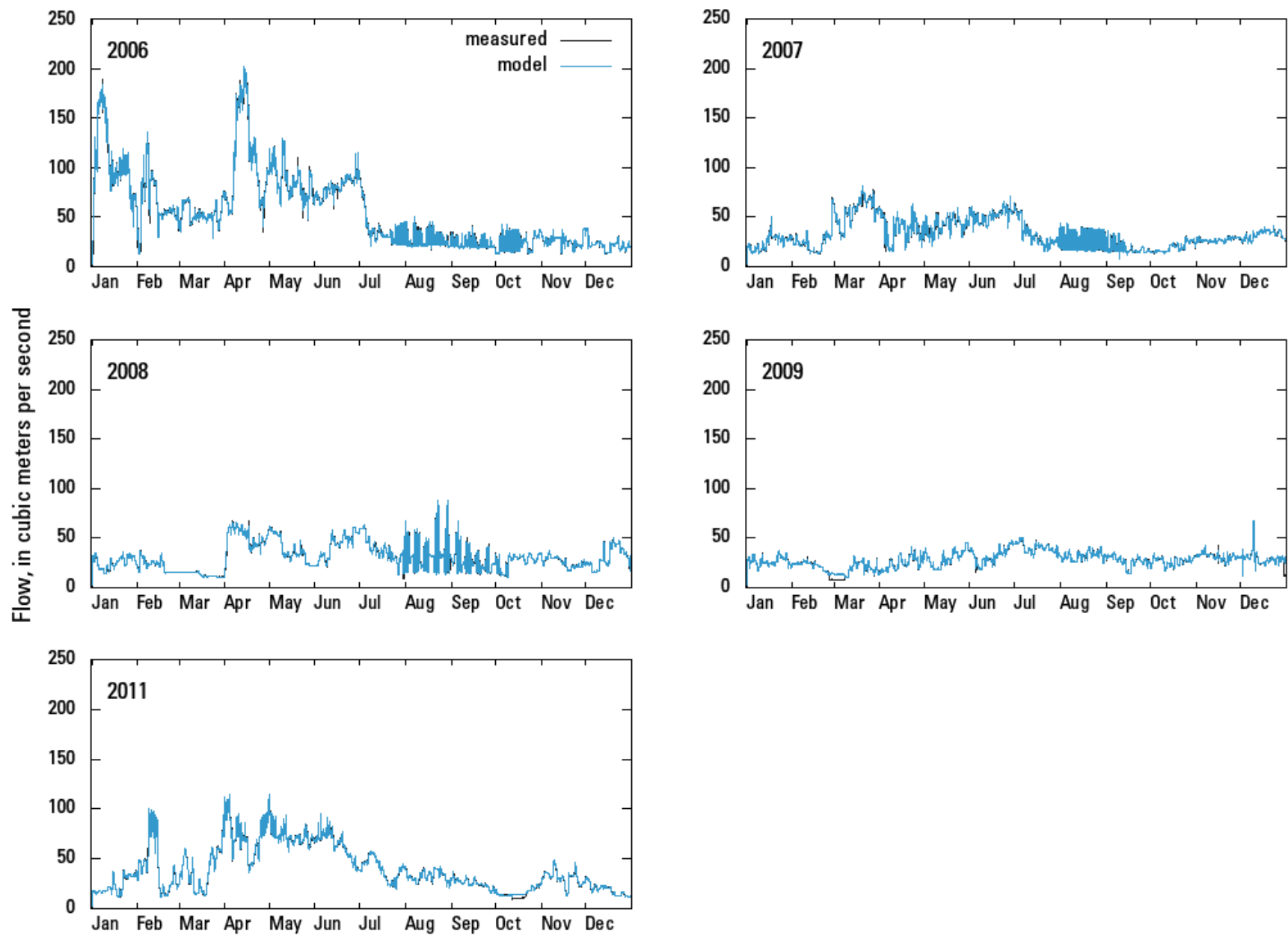

Figure 3. Graphs showing simulated and measured Link River flow at USGS streamgage 11507500, south-central Oregon, 2006-09 and 2011. 

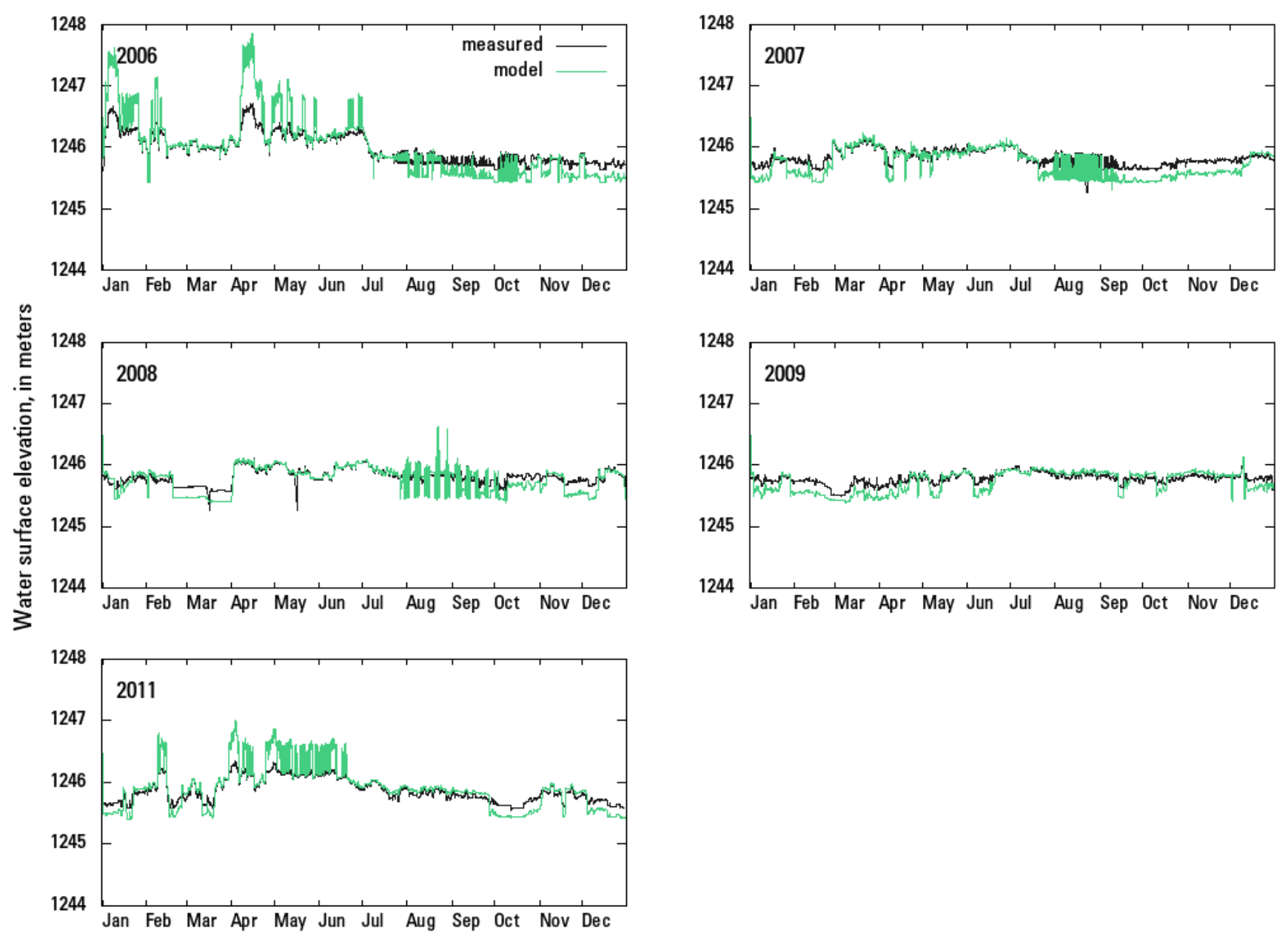

Figure 4. Graphs showing simulated and measured Link River water-surface elevation at USGS streamgage 11507500, south-central Oregon, 2006-09 and 2011.

Simulated water velocities typically ranged from 0.5 to $5.0 \mathrm{~m} / \mathrm{s}(1.6-16 \mathrm{ft} / \mathrm{s})$ (fig. 5). This is in the same range as other measured and simulated Link River flows, including those by Marine and Lappe (2009; measurements from summer 2008 were $0.5-1.1 \mathrm{~m} / \mathrm{s}$ [1.5-3.6 ft/s]) and Mefford and Higgs (2006; modeled values were $1.2-6.0 \mathrm{~m} / \mathrm{s}[3.9-20 \mathrm{ft} / \mathrm{s}]$ for flows of $\left.28-113 \mathrm{~m}^{3} / \mathrm{s}\left[1,000-4,000 \mathrm{ft}^{3} / \mathrm{s}\right]\right)$. Flows of $0.5 \mathrm{~m} / \mathrm{s}$ would traverse the Link River model reach in 1.2 hours; flows of $5 \mathrm{~m} / \mathrm{s}$ would traverse the Link River model reach in about 7 minutes. CE-QUAL-W2 only calculates flows for model segments; thus, the velocities for the falls in Link River, modeled as a break between model segments/waterbodies, were not output. The Link River residence times provide an important context for interpretation of the waterquality results, as little time is available for much heat transfer, algal growth, and other chemical or biological transformations. 


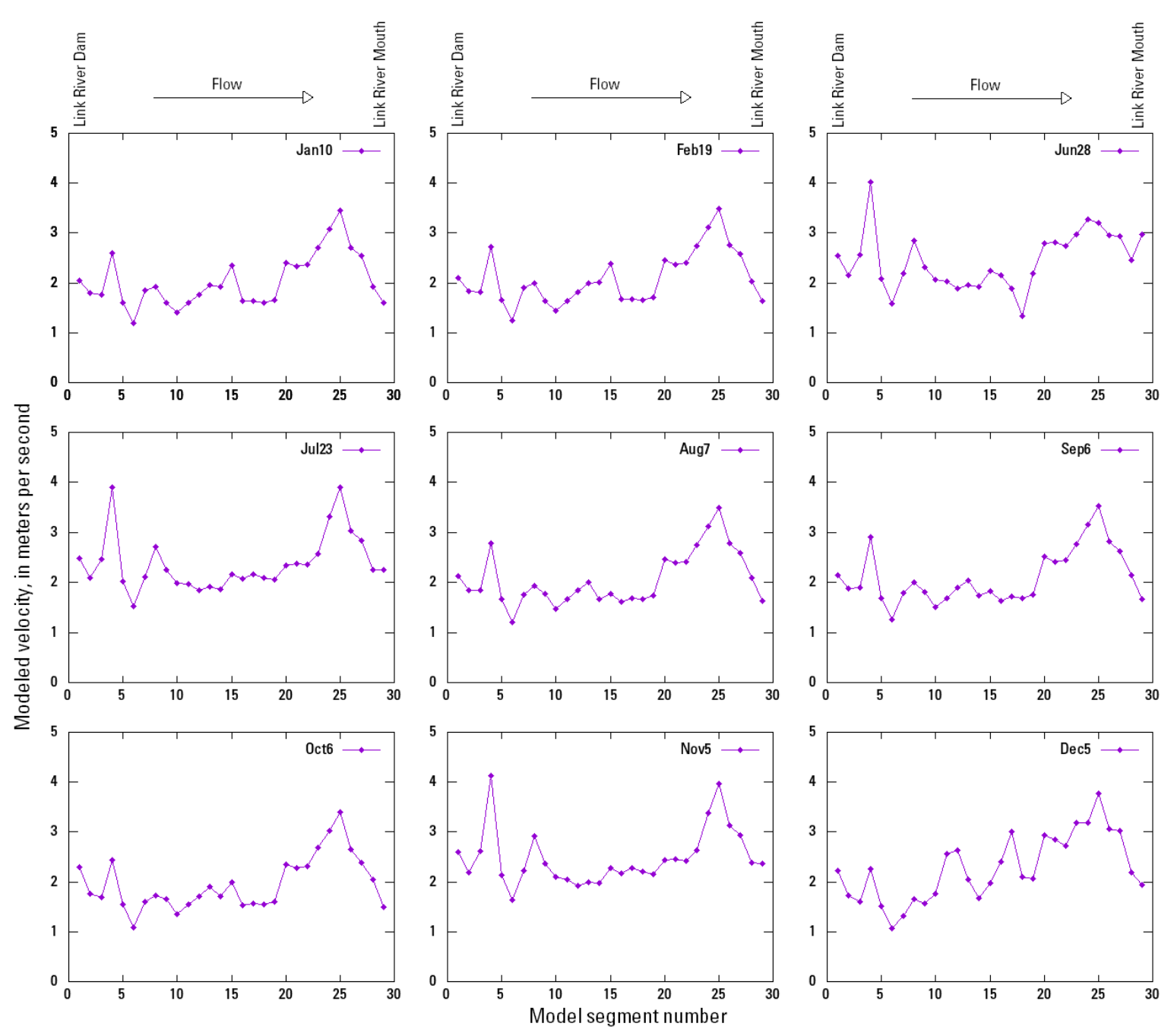

Figure 5. Graphs showing simulated water velocity along Link River, south-central Oregon, for selected days in 2008.

\section{Water Quality}

Water-quality parameters for the Link River model initially were set equal to those for the existing Keno model and modified as necessary to match the properties of the Link River reach, which has more riverine characteristics than the pooled Keno model reach. Parameters that were changed or added during calibration included the vertical turbulence closure algorithm, spillway and dissolved gas coefficients, and parameters related to reaeration and bottom friction (table 1). 
Table 1. Differences in various hydrodynamic and water-quality model parameters for the Link River and Keno models.

[n/a, not applicable]

\begin{tabular}{llll}
\hline \multicolumn{1}{c}{ Parameter } & $\begin{array}{c}\text { Link River } \\
\text { model }\end{array}$ & $\begin{array}{c}\text { Keno } \\
\text { model }\end{array}$ & \multicolumn{1}{c}{ Description } \\
\hline AZC & NICK & TKE & Form of vertical turbulence closure algorithm \\
A1SP & 320 & $\mathrm{n} / \mathrm{a}$ & $\alpha 1$, empirical coefficient for free-flowing conditions \\
B1SP & 1.5 & $\mathrm{n} / \mathrm{a}$ & $\beta 1$, empirical coefficient for free-flowing conditions \\
A2SP & 20 & $\mathrm{n} / \mathrm{a}$ & $\alpha 2$, empirical coefficient for submerged conditions \\
B2SP & 1.5 & $\mathrm{n} / \mathrm{a}$ & $\beta 2$, empirical coefficient for submerged conditions \\
ASP & 1.5 & $\mathrm{n} / \mathrm{a}$ & a coefficient in dissolved gas equation \\
BSP & 0.4 & $\mathrm{n} / \mathrm{a}$ & $\mathrm{b}$ coefficient in dissolved gas equation \\
CSP & $2.8,2.4$ & $\mathrm{n} / \mathrm{a}$ & c coefficient in dissolved gas equation \\
REARATION TYPE & RIVER & LAKE & Type of waterbody \\
EQN & 7 & 14 & Equation number used for determining reaeration \\
FRICTC & 0.04 to 0.03 & 0.02 & Bottom friction \\
SLOPE & 0.00651 branch 1 & 0 & Branch bottom slope \\
& 0.00473 branch 2 & & \\
\hline
\end{tabular}

Goodness-of-fit statistics for water temperature, specific conductance, dissolved oxygen, and $\mathrm{pH}$ were computed by comparing sonde data measured at site 11507501 at Link River Bridge to results from the corresponding model segment. Goodness-of-fit statistics for nutrients, algae, and organic matter were reported by comparing model output to the time series that made up the input to the Keno model. Those time series were based on measurements at site 11507501 collected by USGS and Reclamation (Sullivan and others, 2008, 2009) as well as other measured datasets. Because those same time series were set as the upstream boundary of the model at Link River Dam, owing to sparse data at Link Dam itself, the fit statistics for nutrients and organic matter are more an indication of how and whether those concentrations changed over the Link River reach.

\section{Water Temperature}

Water temperature at Link River Dam displayed a typical annual cycle ranging from a minimum near $0{ }^{\circ} \mathrm{C}$ in winter and maximum greater than $25^{\circ} \mathrm{C}$ in mid-summer. The temperature changed little as water moved through the Link River reach on most days (figs. 2, A1), an indication of the fact that the short residence time of the reach did not allow for a significant amount of heat gain or loss relative to the large thermal mass in the river. Given that short residence time, the model successfully simulated water temperature in Link River, with mean errors (MEs) near zero, and mean absolute errors (MAEs) and root mean square errors (RMSEs) of $0.20^{\circ} \mathrm{C}$ or less (fig. 6, table 2). The model showed Link River to be well-mixed and relatively shallow, with little temperature variability in the vertical dimension. 

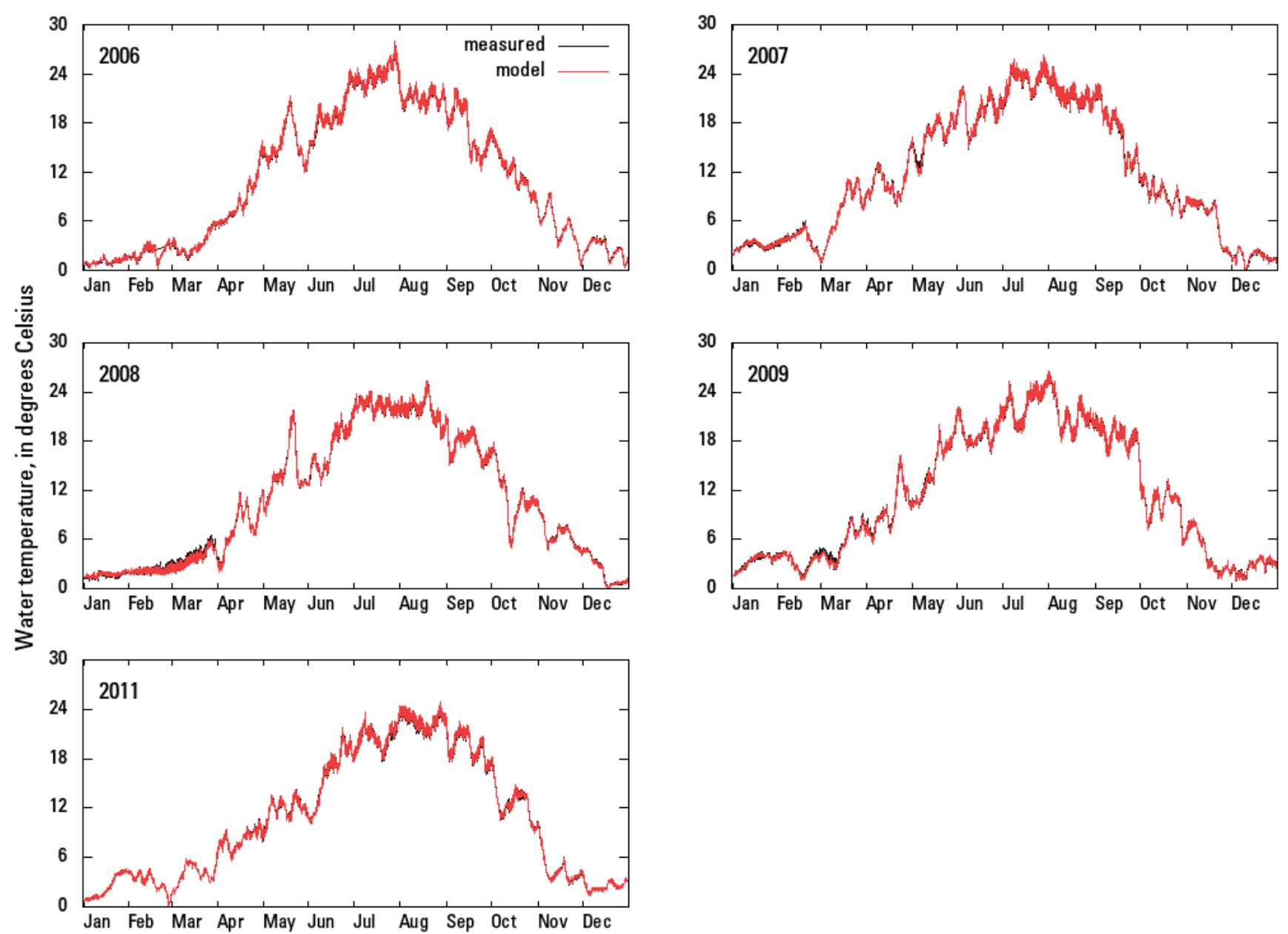

Figure 6. Graphs showing simulated and measured water temperature near mouth of Link River (site 11507501), south-central Oregon, 2006-09 and 2011. 
Table 2. Goodness-of-fit statistics for hourly water-quality results at the outflow of the Link River model to the LinkKeno boundary input file at the same location, which was derived from measured values.

[Fit statistics for water temperature, dissolved oxygen, and specific conductance are true comparisons to data; error statistics for the other constituents are a measure of how much the simulated concentration changed in the Link River reach. Units: $\mu \mathrm{m}^{3} / \mathrm{mL}$, cubic micrometers per milliliter; ${ }^{\circ} \mathrm{C}$, degrees Celsius; $\mathrm{mg} / \mathrm{L}$, milligram per liter; $\mu \mathrm{S} / \mathrm{cm}$, microsiemens per centimeter; $\mathrm{N}$, nitrogen; $\mathrm{P}$, phosphorus]

\begin{tabular}{|c|c|c|c|c|c|c|}
\hline Constituent & Units & Range of values & Year & Mean error & $\begin{array}{c}\text { Mean } \\
\text { absolute error }\end{array}$ & $\begin{array}{l}\text { Root mean } \\
\text { square error }\end{array}$ \\
\hline \multirow[t]{5}{*}{ Water temperature } & \multirow[t]{5}{*}{${ }^{\circ} \mathrm{C}$} & \multirow[t]{5}{*}{$0-27$} & 2006 & 0.04 & 0.13 & 0.17 \\
\hline & & & 2007 & 0.03 & 0.12 & 0.16 \\
\hline & & & 2008 & -0.02 & 0.14 & 0.17 \\
\hline & & & 2009 & -0.02 & 0.14 & 0.18 \\
\hline & & & 2011 & 0.03 & 0.16 & 0.20 \\
\hline \multirow[t]{5}{*}{ Dissolved oxygen } & \multirow[t]{5}{*}{$\mathrm{mg} / \mathrm{L}$} & \multirow[t]{5}{*}{$5-15$} & 2006 & 0.13 & 0.50 & 0.76 \\
\hline & & & 2007 & 0.16 & 0.42 & 0.58 \\
\hline & & & 2008 & 0.01 & 0.48 & 0.63 \\
\hline & & & 2009 & 0.12 & 0.38 & 0.51 \\
\hline & & & 2011 & 0.07 & 0.37 & 0.46 \\
\hline \multirow[t]{5}{*}{ Specific conductance } & \multirow[t]{5}{*}{$\mu \mathrm{S} / \mathrm{cm}$} & \multirow[t]{5}{*}{$95-140$} & 2006 & -1.3 & 2.3 & 3.5 \\
\hline & & & 2007 & 0.5 & 1.5 & 2.0 \\
\hline & & & 2008 & -0.2 & 1.8 & 2.4 \\
\hline & & & 2009 & -1.0 & 1.6 & 2.0 \\
\hline & & & 2011 & 0.8 & 2.1 & 2.9 \\
\hline \multirow[t]{5}{*}{$\mathrm{pH}$} & & \multirow[t]{5}{*}{$7-10.5$} & 2006 & 0.12 & 0.14 & 0.17 \\
\hline & & & 2007 & 0.07 & 0.13 & 0.16 \\
\hline & & & 2008 & -0.04 & 0.14 & 0.50 \\
\hline & & & 2009 & 0.16 & 0.18 & 0.22 \\
\hline & & & 2011 & 0.08 & 0.17 & 0.22 \\
\hline \multirow[t]{5}{*}{ Ammonia } & \multirow[t]{5}{*}{$\mathrm{mg} / \mathrm{L}$ as $\mathrm{N}$} & \multirow[t]{5}{*}{$0-1.6$} & 2006 & 0.002 & 0.002 & 0.003 \\
\hline & & & 2007 & 0.003 & 0.003 & 0.004 \\
\hline & & & 2008 & 0.002 & 0.002 & 0.004 \\
\hline & & & 2009 & 0.001 & 0.001 & 0.002 \\
\hline & & & 2011 & 0.001 & 0.001 & 0.001 \\
\hline \multirow[t]{5}{*}{ Nitrate } & \multirow[t]{5}{*}{$\mathrm{mg} / \mathrm{L}$ as $\mathrm{N}$} & \multirow[t]{5}{*}{$0-0.5$} & 2006 & 0.000 & 0.000 & 0.000 \\
\hline & & & 2007 & 0.000 & 0.000 & 0.000 \\
\hline & & & 2008 & 0.000 & 0.000 & 0.000 \\
\hline & & & 2009 & 0.000 & 0.000 & 0.000 \\
\hline & & & 2011 & 0.000 & 0.000 & 0.000 \\
\hline \multirow[t]{5}{*}{ Orthophosphorus } & \multirow[t]{5}{*}{$\mathrm{mg} / \mathrm{L}$ as $\mathrm{P}$} & \multirow[t]{5}{*}{$0-0.2$} & 2006 & 0.000 & 0.000 & 0.000 \\
\hline & & & 2007 & 0.000 & 0.000 & 0.000 \\
\hline & & & 2008 & 0.000 & 0.000 & 0.000 \\
\hline & & & 2009 & 0.000 & 0.000 & 0.000 \\
\hline & & & 2011 & 0.000 & 0.000 & 0.000 \\
\hline \multirow[t]{5}{*}{ Blue-green algae } & \multirow[t]{5}{*}{$\mu \mathrm{m}^{3} / \mathrm{mL}$} & \multirow[t]{5}{*}{$0-1.1 \mathrm{E}+08$} & 2006 & $-1.3 \times 10^{5}$ & $1.3 \times 10^{5}$ & $2.5 \times 10^{5}$ \\
\hline & & & 2007 & $-1.4 \times 10^{5}$ & $1.5 \times 10^{5}$ & $2.8 \times 10^{5}$ \\
\hline & & & 2008 & $-1.2 \times 10^{5}$ & $1.2 \times 10^{5}$ & $2.3 \times 10^{5}$ \\
\hline & & & 2009 & $-7.1 \times 10^{4}$ & $7.3 \times 10^{4}$ & $1.3 \times 10^{5}$ \\
\hline & & & 2011 & $-3.2 \times 10^{4}$ & $3.2 \times 10^{4}$ & $6.7 \times 10^{4}$ \\
\hline
\end{tabular}


Despite the steep canyon walls and the riparian shade along Link River, model results showed that the addition of shade to the model had little effect on water temperature. The maximum difference between a model with no shade and a model that included both riparian and topographic shade was only $0.04{ }^{\circ} \mathrm{C}$. Two main reasons account for this small effect. First, the travel time of water through the reach was short, so that shade did not have much time to affect water temperature. Second, although there were times when the river was entirely shaded, this typically was only during the morning or early evening hours (given the generally north-south orientation of Link River), periods when solar radiation was low. Correspondingly, the small temperature differences that did occur generally were present in the morning and late afternoon or evening. Considering the two types of shade, riparian shade had a greater effect on water temperature than did topographic shade, but neither was particularly significant.

\section{Specific Conductance}

Specific conductance is a measure of the concentration of dissolved ions, and can be linearly related to the concentration of total dissolved solids (TDS) using a conversion factor (TDS $=0.69 *$ Specific Conductance) as applied to the Klamath River by Sullivan and others (2011). TDS is one of the standard constituents modeled by CE-QUAL-W2. For the Link River model, measured specific conductance data were converted to TDS for modeling work and then TDS results were converted back to specific conductance to compare to field measurements.

At Link River Dam, specific conductance values ranged from 95 to $140 \mu \mathrm{S} / \mathrm{cm}$ in the years modeled (fig. 2); these values are low considering the range of possible specific conductance values found in natural waters (Hem, 1985). Specific conductance values generally were highest in winter and early spring. Some elevated values in summer also occurred and were accompanied by daily variations that are likely related to phytoplankton activity in summer. The Link River model simulated specific conductance well, with ME, MAE and RMSE values of $3.5 \mu \mathrm{S} / \mathrm{cm}$ or less (fig. 7, table 2). The model underpredicted specific conductance by about $5-10 \mu \mathrm{S} / \mathrm{cm}$ for a period in late autumn 2006 . The discrepancy likely is owing to uncertainties in the measured specific conductance at either the upstream or downstream locations, as the model did a good job of translating the upstream conditions through the modeled reach, but that time period was one when the upstream and downstream specific conductance values were somewhat dissimilar. 

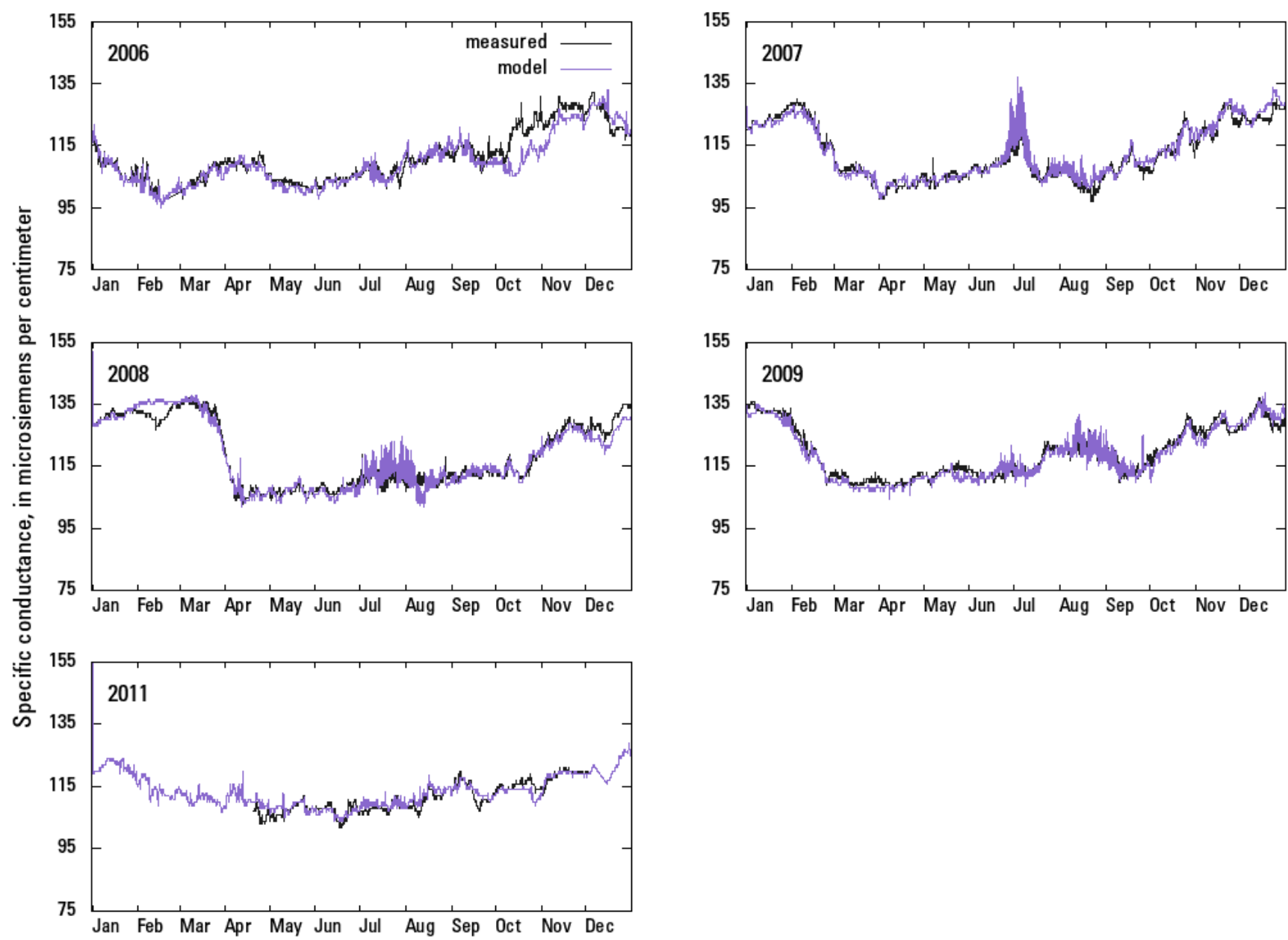

Figure 7. Graphs showing simulated and measured specific conductance near mouth of Link River (site 11507501), south-central Oregon, 2006-09 and 2011. 


\section{Nutrients, Organic Matter, and Algae}

Orthophosphorus, dissolved and particulate organic matter, and blue-green algae concentrations had elevated concentrations at Link River Dam in summer in conjunction with the typical summertime algal blooms. By contrast, ammonia and nitrate concentrations typically were highest at Link River Dam in winter, as these dissolved nutrients are not taken up by algal growth during the cold Klamath Falls winters. The short travel time in the Link River reach meant that concentrations typically did not change much from Link River Dam to Link River mouth for nutrients, organic matter, and algae. This was true for ammonia, nitrate, and orthophosphorus in most years (table 2). The Link River model simulated settling of some blue-green algae to the riverbed, as indicated by the negative ME in all years (table 2), although the amounts of algae lost, on the order of $1.0 \times 10^{5} \mu \mathrm{m}^{3} / \mathrm{mL}$, were small relative to the range of values, as much as $1.0 \times 10^{8} \mu \mathrm{m}^{3} / \mathrm{mL}$. Preliminary results from another study in Link River have indicated that blue-green algae may be physically fragmented in this reach, but more analysis is needed (Mike Deas, Watercourse Engineering, Inc., written commun., 2015).

$\mathrm{pH}$

At Link River Dam, $\mathrm{pH}$ typically was near neutral in winter and increased to values greater than 9.0 or even 10.0 during periods in spring and summer (fig. 2). Elevated pH typically is associated with phytoplankton blooms in the hypereutrophic Upper Klamath Lake and Klamath River systems. The small change in $\mathrm{pH}$ in the Link River reach between Link River Dam and Link River mouth was simulated by the model (fig. 8), with MAE and RMSE values of 0.50 or less (table 2). The version of CE-QUAL-W2 used in this study had been updated with an improved $\mathrm{pH}$ algorithm that accounts for the effects of dissolved organic matter, ammonia, and orthophosphorus on $\mathrm{pH}$ buffering (Sullivan and others, 2013). 

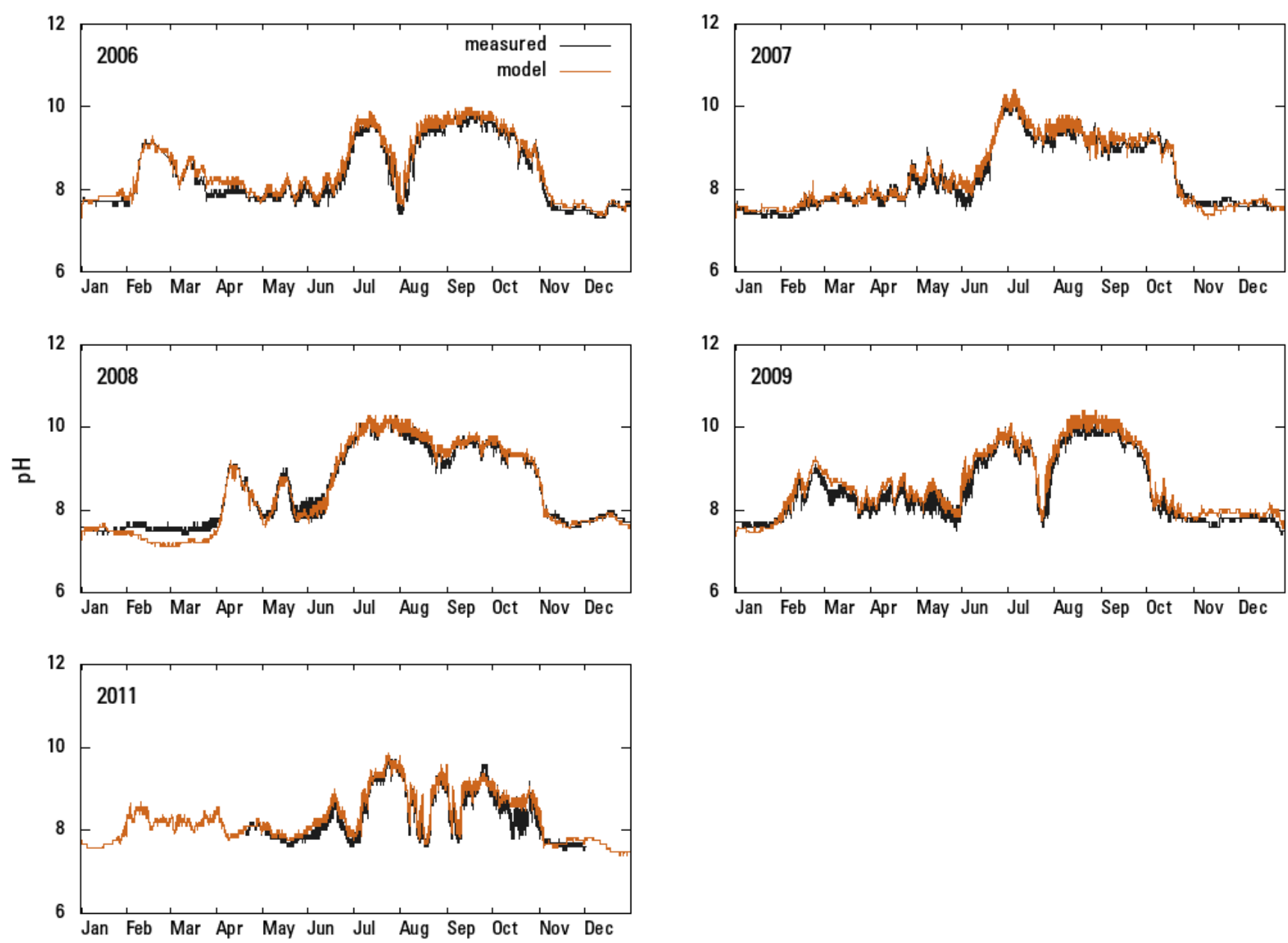

Figure 8. Graphs showing simulated and measured pH near mouth of Link River (site 11507501), south-central Oregon, 2006-09 and 2011. 


\section{Dissolved Oxygen}

Dissolved oxygen concentrations at Link River Dam were elevated in winter, largely because of a higher solubility in cold winter water, with little daily variability. In summer, during phytoplankton blooms, dissolved oxygen concentrations had much daily variability, and also had periods of low concentrations (fig. 2). Reaeration between Link River Dam and Link River mouth brought dissolved oxygen concentrations closer to saturation. The Link River model captured this process and the resulting concentration patterns (figs. 9-10) with ME less than 0.20 and RMSE less than $0.80 \mathrm{mg} / \mathrm{L}$ (table 2). In the model, most reaeration occurred where the model grid simulated cascades with steep drops in elevation, at the falls in Link River and just upstream of the braided section (fig. 11). When the East Side and West Side power plants were operating, they could affect instream dissolved oxygen concentrations. Examples of this can be seen in figure 11, near segment 19, for June 28 and December 5; the East Side and West Side plants were not operating on the other days shown in figure 11. Because those inputs to the reach do not have any measured water-quality data available, this represents a source of uncertainty in the model. Those boundary conditions were set equal to conditions measured at the Link River Dam site, but water-quality changes possibly could have occurred as water flowed to the powerhouses; there may have been some reaeration, too, as water passed through those powerhouses. Another source of uncertainty in dissolved oxygen modeling is the fact that Link Dam and any associated reaeration were not simulated in the model, causing the model parameters to have to overcompensate and simulate more reaeration in the Link River channel. 

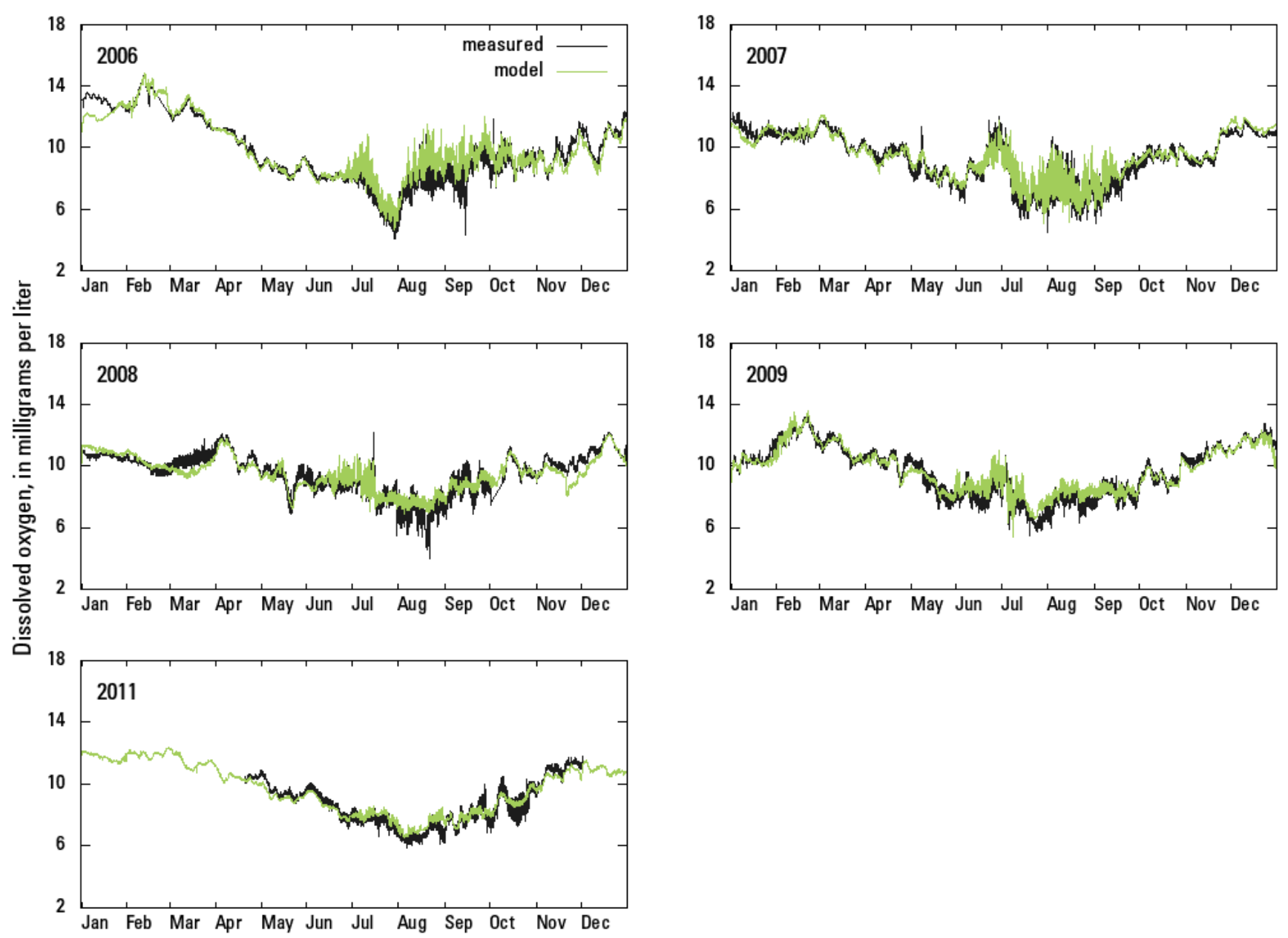

Figure 9. Graphs showing simulated and measured dissolved oxygen near mouth of Link River (site 11507501), south-central Oregon, 2006-09 and 2011. 

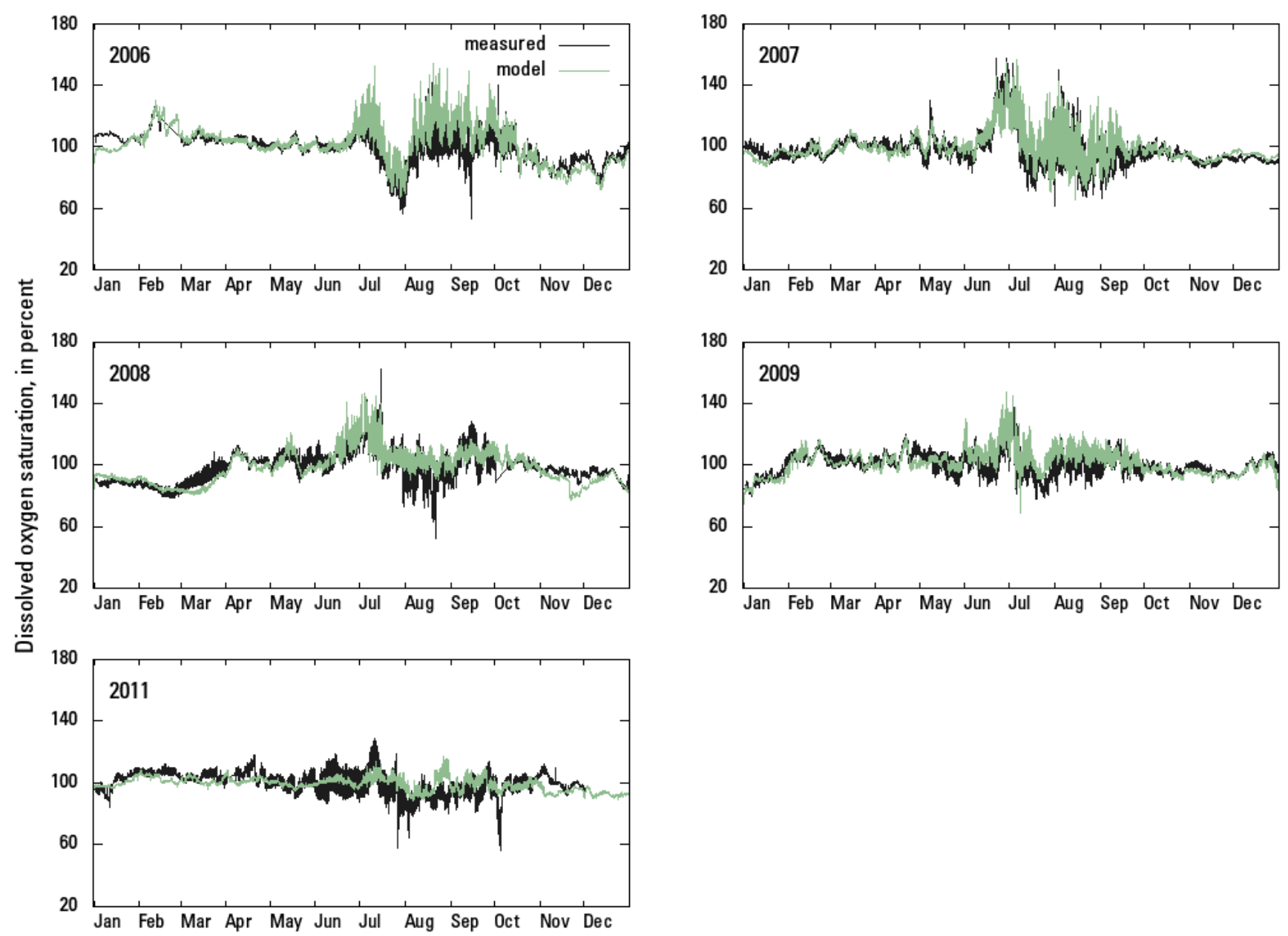

Figure 10. Graphs showing simulated and measured dissolved oxygen saturation near mouth of Link River (site 11507501), south-central Oregon, 2006-09 and 2011. 

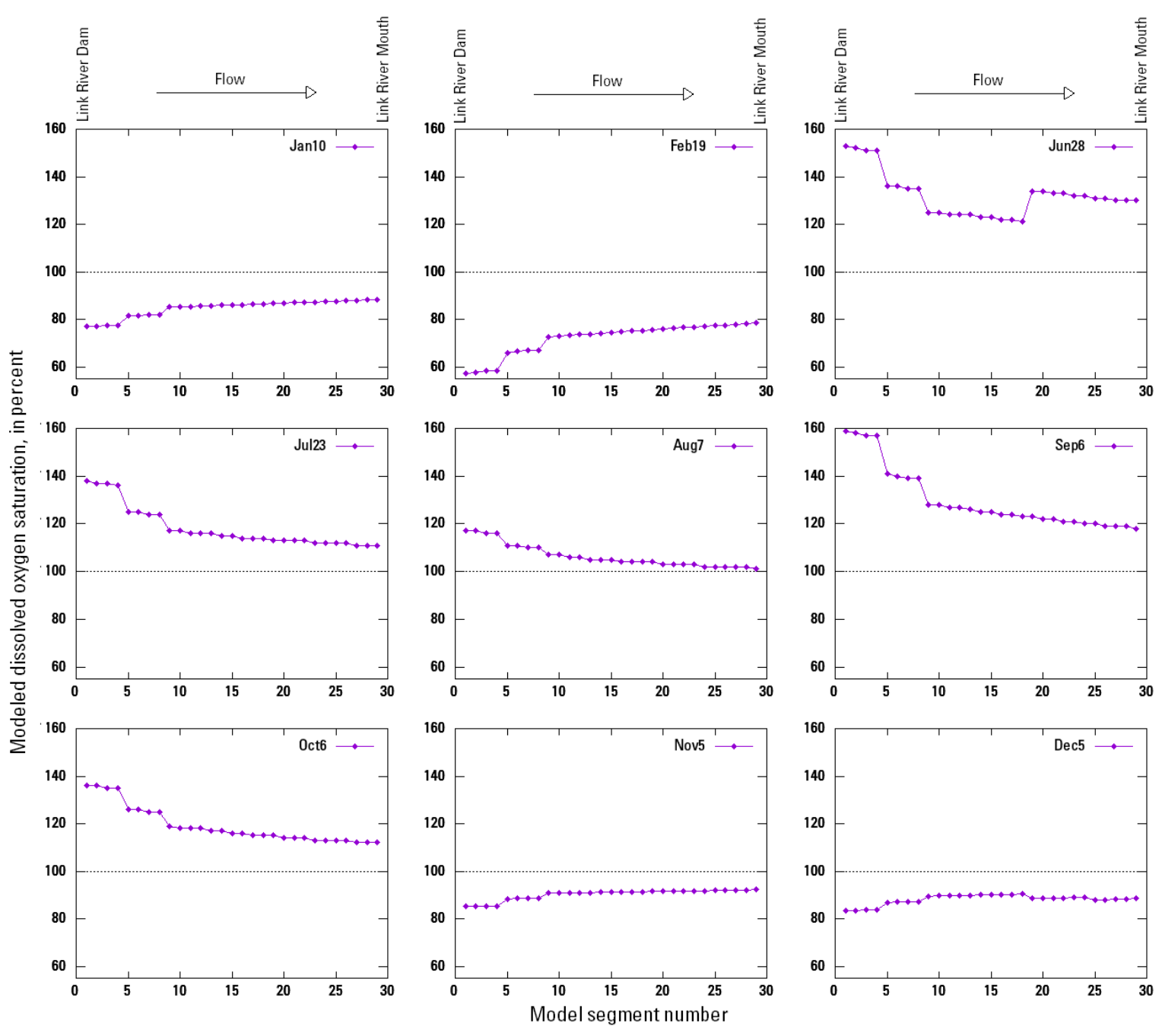

Figure 11. Graphs showing simulated dissolved oxygen saturation along Link River, south-central Oregon, for selected days in 2008. On each $\mathrm{x}$-axis, Link River Dam is on the left and Link River mouth is on the right. 


\section{Summary}

A defining feature of Link River is the short travel time for water, less than 2 hours for typical flows. The short travel time means that typical processes that affect water quality and water temperature, such as shade, decay, and uptake, did not have much of an effect in Link River. Instead, with one notable exception, water quality at Link River mouth was similar to that at Link River Dam. This means that processes that occurred in Upper Klamath Lake largely determined Link River water quality.

Dissolved oxygen was the one constituent that changed greatly in Link River. Reaeration in this steep river was significant and brought water that entered supersaturated or undersaturated closer to saturation by the time water exited the reach at Link River mouth. This reaeration is particularly notable because it helps to determine the dissolved oxygen concentration flowing into the Klamath River, which, in many years, has low dissolved oxygen. Although Link River reaeration can reset the dissolved oxygen concentrations closer to saturation, the water still contains a load of oxygen-demanding substances (organic matter, for instance) that is expressed farther downstream in the Keno Dam reach of the Klamath River.

A rationale for developing the Link River model was to allow future connection to upstream and downstream models, so that whole basin management scenarios could be examined. Connecting the Link River model to the downstream Keno model is straightforward because the same model was used for both reaches. Future connection to upstream Upper Klamath Lake models will require some coordination to assure smooth connection between those models.

\section{Acknowledgments}

Field work along Link River was carried out by J.R. Schanzenbacher (Bureau of Reclamation) with assistance by other members of the Reclamation field crew. Jackie Olson (USGS) assisted with GIS analyses for shade input file development. Discussions with Mike Deas (Watercourse Engineering, Inc.) and Rick Carlson (Reclamation) were helpful during the course of the study.

\section{References Cited}

Anderson, L.C.D., and Bruland, K.W., 1991, Biogeochemistry of arsenic in natural waters-The importance of methylated species: Environmental Science and Technology, v. 25, p. 420-427.

Cole, T.M., and Wells, S.A., 2008, CE-QUAL-W2-A two-dimensional, laterally averaged, hydrodynamic and water-quality model, version 3.6: U.S. Army Corps of Engineers, Instruction Report EL-08-1 [variously paged].

Fishman, M.J., ed., 1993, Methods of analysis by the U.S. Geological Survey National Water Quality Laboratory-Determination of inorganic and organic constituents in water and fluvial sediments: U.S. Geological Survey Open-File Report 93-125, 217 p.

Garbarino, J.R., Kanagy, L.K., and Cree, M.E., 2005, Determination of elements in natural-water, biota, sediment and soil samples using collision/reaction cell inductively coupled plasma-mass spectrometry: U.S. Geological Survey Techniques and Methods, book 5, chap. B1, 88 p.

Hem, J.D., 1985, Study and interpretation of the chemical characteristics of natural water: U.S. Geological Survey Water Supply Paper 2254, 263 p.

Marine, K.R., and Lappe, P., 2009, Link River Dam surface spill experiment—Evaluation of differential juvenile sucker downstream passage rates: Final report prepared for the Bureau of Reclamation [variously paged].

Mefford, B., and Higgs, J., 2006, Link River Falls fish passage investigation-Flow velocity simulation: Bureau of Reclamation, Water Resources Research Laboratory Technical Paper 954, 29 p. 
PacifiCorp, 2004a, Final license application, Exhibit A-Project Description, Klamath Hydroelectric Project, FERC Project No. 2082: Portland, Oregon, PacifiCorp [variously paged].

PacifiCorp, 2004b, Final technical report, Klamath Hydroelectric Project, (FERC Project No. 2082) -

Terrestrial resources: Portland, Oregon, PacifiCorp [variously paged].

PacifiCorp, 2005, Klamath Hydroelectric Project (FERC Project No. 2012) response to November 10, 2005 FERC AIR GN-2 - Klamath River water quality model implementation, calibration, and validation: Portland, Oregon, PacifiCorp, $91 \mathrm{p}$.

Patton, C.J., and Kryskalla, J.R., 2003, Methods of analysis by the U.S. Geological Survey National Water Quality Laboratory-Evaluation of alkaline persulfate digestion as an alternative to Kjeldahl digestion for determination of total and dissolved nitrogen and phosphorus in water: Water-Resources Investigations Report 03-4174, 33 p.

Patton, C.J., and Kryskalla, J.R., 2011, Colorimetric determination of nitrate plus nitrite in water by enzymatic reduction, automated discrete analyzer methods: U.S. Geological Survey Techniques and Methods, book 5, chap. B8.

Senn, D.B., and Hemond, H.F., 2004, Particulate arsenic and iron during anoxia in a eutrophic urban lake: Environmental Toxicology and Chemistry, v. 23, p. 1,610-1,616.

Sullivan, A.B., Deas, M.L., Asbill, J., Kirshtein, J.D., Butler, K., and Vaughn, J., 2009, Klamath River water quality data from Link River Dam to Keno Dam, Oregon, 2008: U.S. Geological Survey Open File Report 2009-1105, 25 p. [Also available at http://pubs.usgs.gov/of/2009/1105/.]

Sullivan, A.B., Deas, M.L., Asbill, J., Kirshtein, J.D., Butler, K., Wellman, R.W., Stewart, M.A., and Vaughn, J., 2008, Klamath River water quality and acoustic Doppler current profiler data from Link River Dam to Keno Dam, 2007: U.S. Geological Survey Open-File Report 2008-1185, 25 p. [Also available at http://pubs.usgs.gov/of/2008/1185/.]

Sullivan, A.B., Rounds, S.A., Asbill-Case, J.R., and Deas, M.L., 2013, Macrophyte and pH buffering updates to the Klamath River water-quality model upstream of Keno Dam, Oregon: U.S. Geological Survey Scientific Investigations Report 2013-5016, 52 p. [Also available at http://pubs.usgs.gov/sir/2013/5016/.]

Sullivan, A.B., Rounds, S.A., Deas, M.L., Asbill, J.R., Wellman, R.E., Stewart, M.A., Johnston, M.W., and Sogutlugil, I.E., 2011, Modeling hydrodynamics, water temperature, and water quality in the Klamath River upstream of Keno Dam, Oregon, 2006-09: U.S. Geological Survey Scientific Investigations Report 2011-5105, 70 p. [Also available at http://pubs.usgs.gov/sir/2011/5105/.]

Tetra Tech, 2009, Klamath River model for TMDL development: Prepared for U.S. Environmental Agency Regions 9 and 10, Oregon Department of Environmental Quality, and North Coast Regional Water Quality Control Board, 196 p., accessed May 20, 2011, at http://www.deq.state.or.us/wq/tmdls/docs/klamathbasin/uklost/KlamathLostAppendixC.pdf.

U.S. Geological Survey, 2011, Change to solubility equations for oxygen in water: U.S. Geological Survey Office of Water Quality Technical Memorandum 2011.03, accessed March 11, 2016 at http://water.usgs.gov/admin/memo/QW/qw11.03.pdf. 


\section{Appendix A. Link River Synoptic Water Quality Sampling, 2013-15}

To support Link River model development, 4-6 sites along Link River were sampled for field parameters (water temperature, specific conductance, $\mathrm{pH}$, dissolved oxygen, and turbidity), nutrients, arsenic, and iron eight times between August 2013 and January 2015 by Reclamation staff. Sites were selected to encompass the start and end of Link River as well as several intermediate sites in the nonbraided part of Link River.

\section{Methods}

Link River sites were sampled on August 14 and September 4, 2013; May 14, June 11, July 10, August 12, and October 8, 2014; and January 6, 2015. The cooler with samples from May 14 was delayed and arrived at the USGS National Water Quality Laboratory (NWQL) with a temperature that exceeded USGS quality control specifications, so those nutrient samples were not analyzed; arsenic and iron samples are not temperature-sensitive, however, so those samples were analyzed. Sites were sampled from upstream to downstream during each day of data collection in an attempt minimize issues associated with sampling different water parcels as they were transported through the reach. It was not possible to track a single parcel of water, however, as the reach tends to have travel times of minutes to just over 1 hour depending on flow conditions. On some sampling days, six sites (table A1; fig. 1) were sampled. On other days, only four of the sites were visited, but the sites were sampled twice on those days, typically once in the morning and once in the afternoon. The two-a-day sampling was done to ascertain whether nutrient trends differed depending on time of day because of, for example, aquatic plants or biota taking up different amounts of nutrients at different times of the day or from sunlightcontrolled photochemical reactions.

Table A1. Water-quality site locations for sampling in Link River, south-central Oregon, 2013-2015.

[Site locations are shown in figure 1]

\begin{tabular}{|c|c|c|c|c|}
\hline Number & Site name & Short site name & USGS site ID & Latitude/longitude \\
\hline 1 & Link River Dam & Link Dam & 421401121480900 & $42^{\circ} 14^{\prime} 01^{\prime \prime}, 121^{\circ} 48^{\prime} 09^{\prime \prime}$ \\
\hline 2 & $\begin{array}{l}\text { Link River below Link River } \\
\text { Dam }\end{array}$ & $\begin{array}{l}\text { Below Link } \\
\text { Dam }\end{array}$ & 421359121480700 & $42^{\circ} 13^{\prime} 59.8^{\prime \prime}, 121^{\circ} 48^{\prime} 07.0^{\prime \prime}$ \\
\hline 3 & $\begin{array}{l}\text { Link River below Falls, at } \\
\text { Klamath Falls }\end{array}$ & $\begin{array}{l}\text { Below Link } \\
\text { Falls }\end{array}$ & 421353121480200 & $42^{\circ} 13^{\prime} 53.5^{\prime \prime}, 121^{\circ} 48^{\prime} 02.1^{\prime \prime}$ \\
\hline 4 & $\begin{array}{l}\text { Link River above East Side } \\
\text { Powerhouse }\end{array}$ & Above East PH & 421330121474700 & $42^{\circ} 13^{\prime} 30.1^{\prime \prime}, 121^{\circ} 47^{\prime} 47.3^{\prime \prime}$ \\
\hline 5 & $\begin{array}{l}\text { Link River upstream of West } \\
\text { Side Canal Spillway }\end{array}$ & $\begin{array}{l}\text { Above West } \\
\text { Canal }\end{array}$ & 11507500 & $42^{\circ} 13^{\prime} 19.9^{\prime \prime}, 121^{\circ} 47^{\prime} 41.7^{\prime \prime}$ \\
\hline 6 & $\begin{array}{l}\text { Link River below West Side } \\
\text { Canal, near Klamath Falls, } \\
\text { Oregon }\end{array}$ & Link Bridge & 11507501 & $42^{\circ} 13^{\prime} 10^{\prime \prime}, 121^{\circ} 47^{\prime} 21^{\prime \prime}$ \\
\hline
\end{tabular}


At each sampling, a water-quality sonde was used to collect data on water temperature, dissolved oxygen, $\mathrm{pH}$, specific conductance, and turbidity. Measurements of air temperature, wind speed and direction, secchi depth, sky cover, and algal bloom condition also were collected. Dissolved oxygen saturation was calculated with the Benson and Krause equations (U.S. Geological Survey, 2011) using measured Klamath Falls barometric pressure for the pressure term and measured specific conductance converted for the salinity term.

At the Link River Dam and Link River Bridge (at Link River mouth) sites, samples for analysis were collected with a Van Dorn sampler at about $0.5 \mathrm{~m}$ (1.6 ft) depth. For sites along Link River, samples were taken from the right bank, reaching out into the channel with a long-handled dip sampler.

Unfiltered samples were collected for analysis of total nitrogen and total phosphorus, and preserved with sulfuric acid. Filtered samples $(0.45-\mu \mathrm{m}$ filter pore size $)$ were collected for orthophosphorus, nitrite plus nitrate, and ammonia in opaque bottles without preservative. At only the Link River mouth site (site 11507501), and only in 2014-15, samples for total and dissolved iron and arsenic also were collected and acidified with nitric acid. Samples were kept on ice and shipped overnight to the USGS NWQL for analysis.

Total phosphorus and total nitrogen concentrations were determined by alkaline persulfate digestion (Patton and Kryskalla, 2003). Orthophosphorus was determined by colorimetry by reaction with ammonium molybdate in acidic solution to form phosphomolybdic acid, then reduction with ascorbic acid (Fishman, 1993). Nitrite plus nitrate was analyzed by enzymatic reduction and colorimetry (Patton and Kryskalla, 2011). Ammonia was measured by colorimetry through reaction with salicylate and hypochlorite in the presence of ferricyanide ions (Fishman, 1993). Iron was analyzed with inductively coupled plasma atomic emission spectrometry (Fishman, 1993). Arsenic was analyzed with inductively coupled plasma mass spectrometry (Garbarino and others, 2005). All concentrations for nitrogen constituents are stated in $\mathrm{mg} / \mathrm{L}$ as $\mathrm{N}$, and all concentrations reported for phosphorus constituents are reported as $\mathrm{mg} / \mathrm{L}$ as $\mathrm{P}$.

Duplicates, field blanks, and laboratory blanks were collected over the course of the sampling project. All blank results were less than reporting levels, except one total phosphorus field blank of $0.012 \mathrm{mg} / \mathrm{L}$, just over the $0.010 \mathrm{mg} / \mathrm{L}$ reporting level. On August 12, 2014, samples were taken at two locations across the channel, one closer to left bank and one closer to right bank at Link River Dam and Link River Bridge, to examine lateral variability at those sites. Left-right differences were less than 16 percent at both sites for all constituents. Samples to examine lateral variability were not collected at other Link River sites because of access issues and swift channel velocity, but observations of the level of turbulence in the river indicated that the river was likely to be well mixed at sites where the dip sampler was used from the river bank.

\section{Results}

\section{Field Parameters}

Water temperature at Link River sites differed by less than $1{ }^{\circ} \mathrm{C}$ during each sampling run. In summer, there sometimes were small differences, with lower temperatures at upstream sites and slightly warmer temperatures at downstream sites (fig. A1).This likely occurred because sites were sampled in an upstream-to-downstream direction, so that upstream sites were sampled in the cool morning and downstream sites were sampled in the warm late morning or early afternoon.

$\mathrm{pH}$ conditions at Link River sites differed by a maximum of 0.6 units during each sampling event. Trends varied; some samplings showed small increases upstream-to-downstream, and some samplings showed small decreases upstream-to-downstream (fig. A1) 

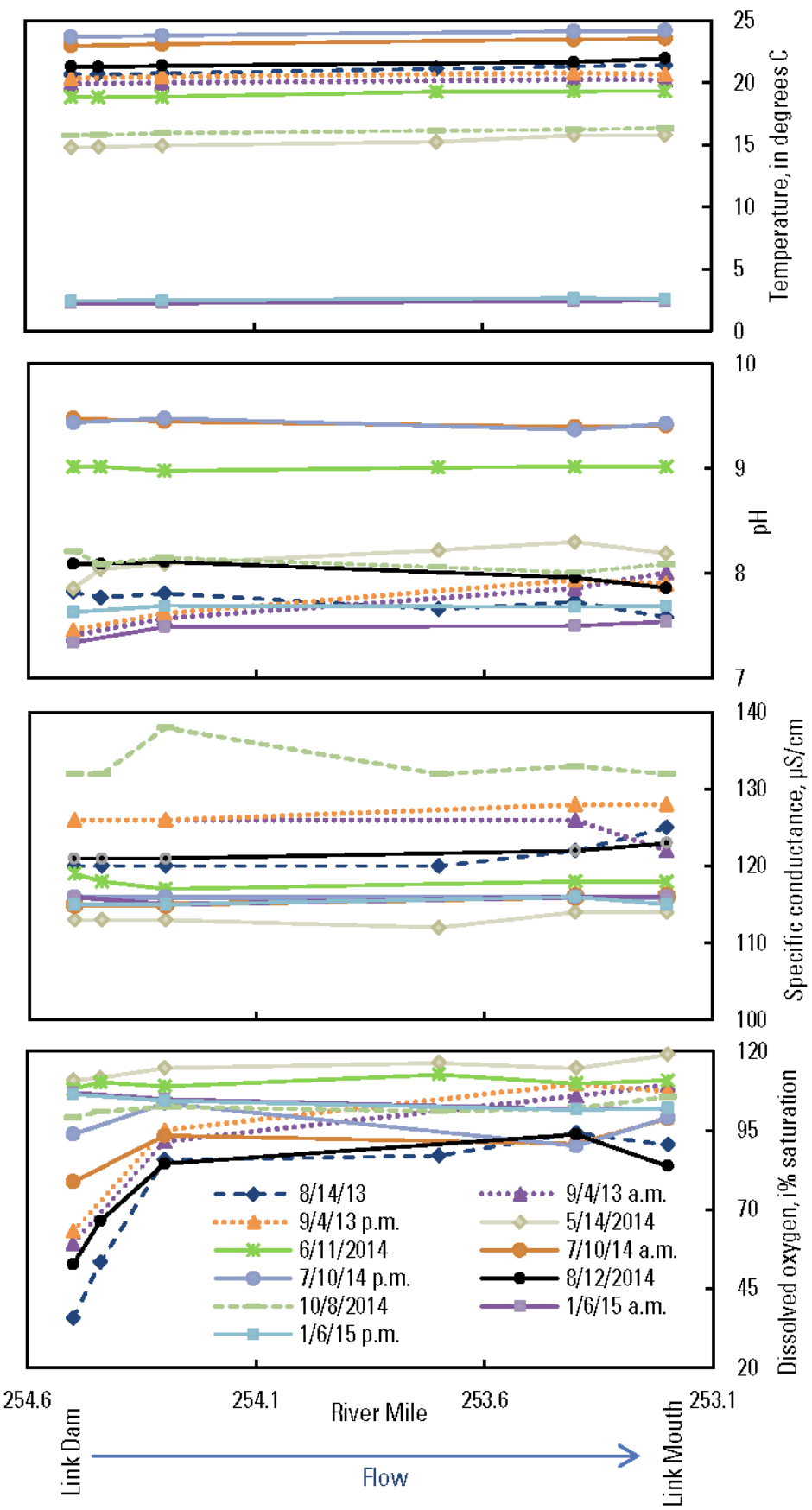

Figure A1. Graphs showing measured water temperature, $\mathrm{pH}$, specific conductance, and dissolved oxygen saturation during sampling events along Link River, south-central Oregon, 2013-15. [Abbreviations: C, Celsius; uS/cm, microsiemens per centimeter; \%, percent.] 
Specific conductance data differed by a maximum of $6 \mu \mathrm{S} / \mathrm{cm}(<5$ percent $)$ at Link River sites during sampling events. No consistent spatial trend was observed for this constituent (fig. A1).

Dissolved oxygen concentrations during samplings differed by a maximum of $4.4 \mathrm{mg} / \mathrm{L}$ (as much as 161 percent). The largest differences occurred when dissolved oxygen concentrations were low (subsaturated) in water from Upper Klamath Lake, and then increased as the water was reaerated passing through Link River Dam and over the falls in Link River. Dissolved oxygen changes were more minor between the falls and Link River Bridge (fig. A1). On most of the sampling runs, dissolved oxygen levels increased from upstream to downstream. On one sampling date in January 2015, oxygen seemed to decrease slightly from upstream to downstream. On this date, oxygen concentrations were slightly supersaturated upstream at Link River Dam.

\section{Nutrients}

Total nitrogen concentrations varied by as much as $0.3 \mathrm{mg} / \mathrm{L}$ between sites during sampling events. Ammonia concentrations varied by as much as $0.1 \mathrm{mg} / \mathrm{L}$, and nitrite plus nitrate concentrations varied by as much as $0.1 \mathrm{mg} / \mathrm{L}$. Total phosphorus concentrations varied by a maximum of $0.1 \mathrm{mg} / \mathrm{L}$ during most individual sampling runs. Orthophosphorus concentrations varied by as much as $0.1 \mathrm{mg} / \mathrm{L}$.

Most nutrient species did not demonstrate a consistent spatial trend. The exception was an increase in nitrite plus nitrate concentration from upstream to downstream during several of the summer sampling events (fig. A2), which could be owing to releases from decomposing organic matter or leaking/respiring algae. The increases in nitrate concentrations do not seem to be associated with decreases in ammonia concentrations; therefore, ammonia nitrification may not be occurring to any appreciable degree, or ammonia losses to nitrification are being offset by other sources of ammonia. 


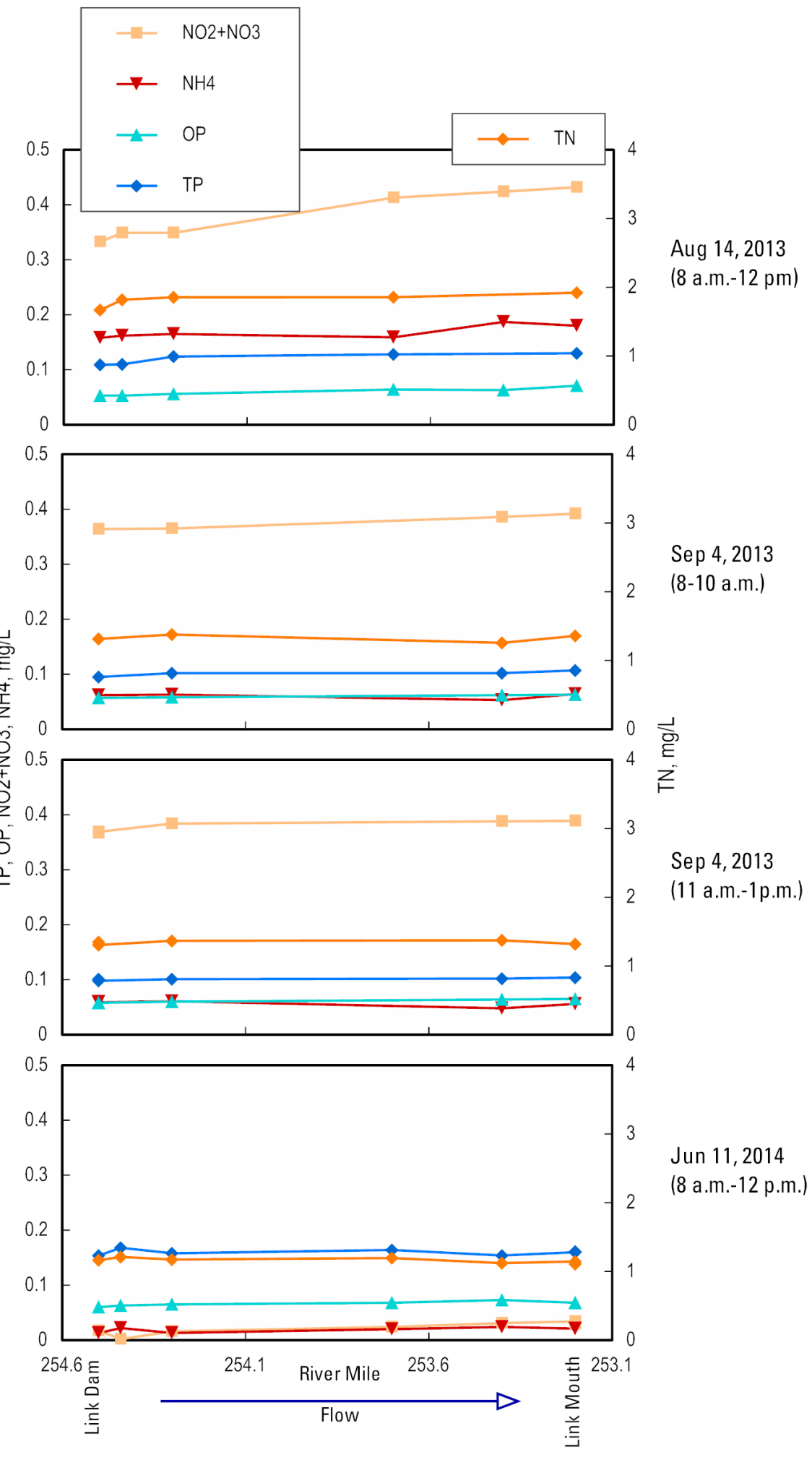

Figure A2. Graphs showing measured total phosphorus, orthophosphorus, total nitrogen, nitrate plus nitrite and ammonia concentrations during sampling events in Link River, south-central Oregon, 2013-15. [Abbreviations: TP, total phosphorus; $\mathrm{OP}$, orthophosphorus; $\mathrm{NO}_{2}+\mathrm{NO}_{3}$, nitrite plus nitrate; $\mathrm{NH}_{4}$, ammonia; $\mathrm{TN}$, total nitrogen; mg/L, milligrams per liter.] 


\section{Arsenic and Iron}

Arsenic at Link River mouth was found mostly in the dissolved phase (passing through a 0.45 $\mu \mathrm{m}$ filter) (fig. A3). The percentage of dissolved arsenic ranged from 82 to 103 percent, with a median of 95 percent dissolved. (Note: values greater than 100 percent are a result of laboratory measurement variability at low concentrations). "Dissolved" arsenic may consist of inorganic and organic arsenic species such as arsenite, arsenate, monomethylarsonate, and dimethylarsenate (Anderson and Bruland, 1991), or small colloidal material (Senn and Hemond, 2004) that can pass through the filter.
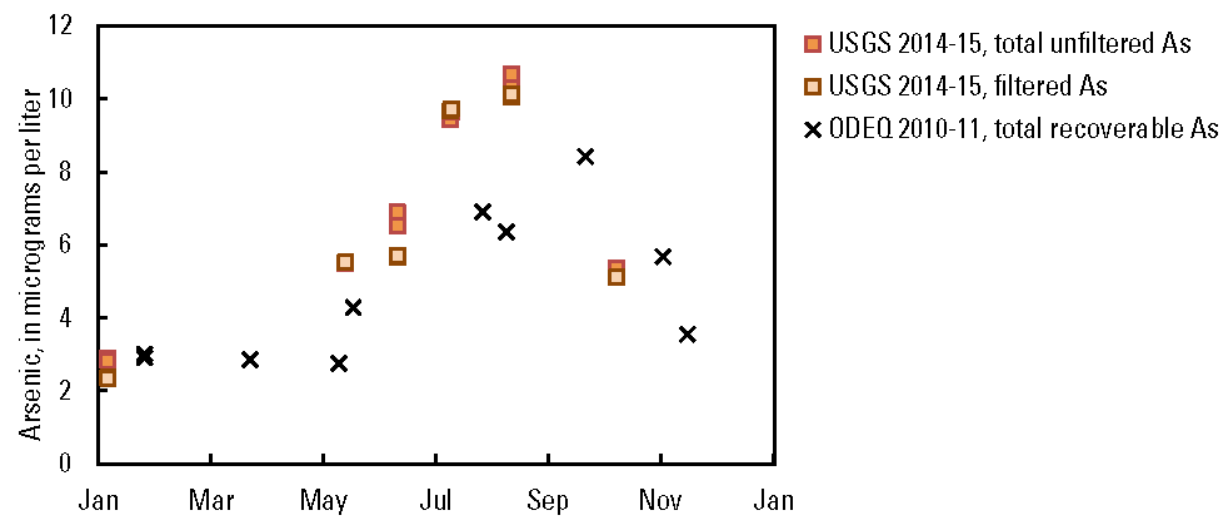

Figure A3. Graph showing total and filtered arsenic concentrations, plotted with arsenic results from Oregon Department of Environmental Quality samplings, at Link River Bridge, south-central Oregon, in different years. Results are plotted without year to show seasonal pattern. [Abbreviation: As, arsenic.]

Total arsenic concentrations ranged from 2.8 to $10.7 \mu \mathrm{g} / \mathrm{L}$ in samples from this study, with the lowest concentration in January and the highest concentration in late summer. This seasonal pattern was similar to seasonal patterns observed in ODEQ arsenic datasets (fig. A3).

Iron at Link River mouth was found both in the dissolved and particulate phases (fig. A4). The percentage of dissolved iron ranged from 27 to 73 percent, with a median of 49 percent. Like arsenic, "dissolved" iron could include truly dissolved species or small colloidal material that could pass through a $0.45-\mu \mathrm{m}$ filter. Particulate iron $(>0.45 \mu \mathrm{m})$ could be associated with clay or soil particles or with algae or particulate organic matter. 


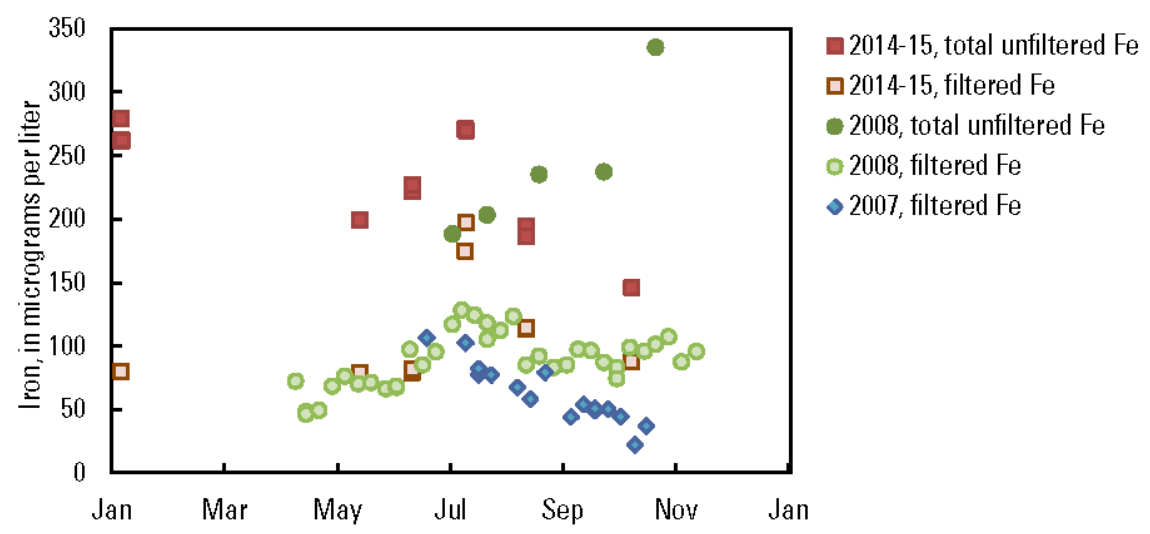

Figure A4. Graph showing total and filtered iron concentrations at Link River Bridge, south-central Oregon. Results are plotted without year to show seasonal pattern. [Abbreviation: Fe, iron.]

Total iron concentrations ranged from 146 to $279 \mu \mathrm{g} / \mathrm{L}$ during samplings in 2014-15. Considering this dataset along with other iron data from Link River collected previously, it appears that there may be some year-to-year variability in the seasonal iron patterns (fig. A4). The highest concentrations of dissolved iron in the 2014-15 dataset occurred in mid-summer. 
Publishing support provided by the U.S. Geological Survey Science Publishing Network, Tacoma Publishing Service Center

For more information concerning the research in this report, contact the Director, Oregon Water Science Center

U.S. Geological Survey

2130 SW 5th Avenue

Portland, Oregon 97201

http://or.water.usgs.gov 


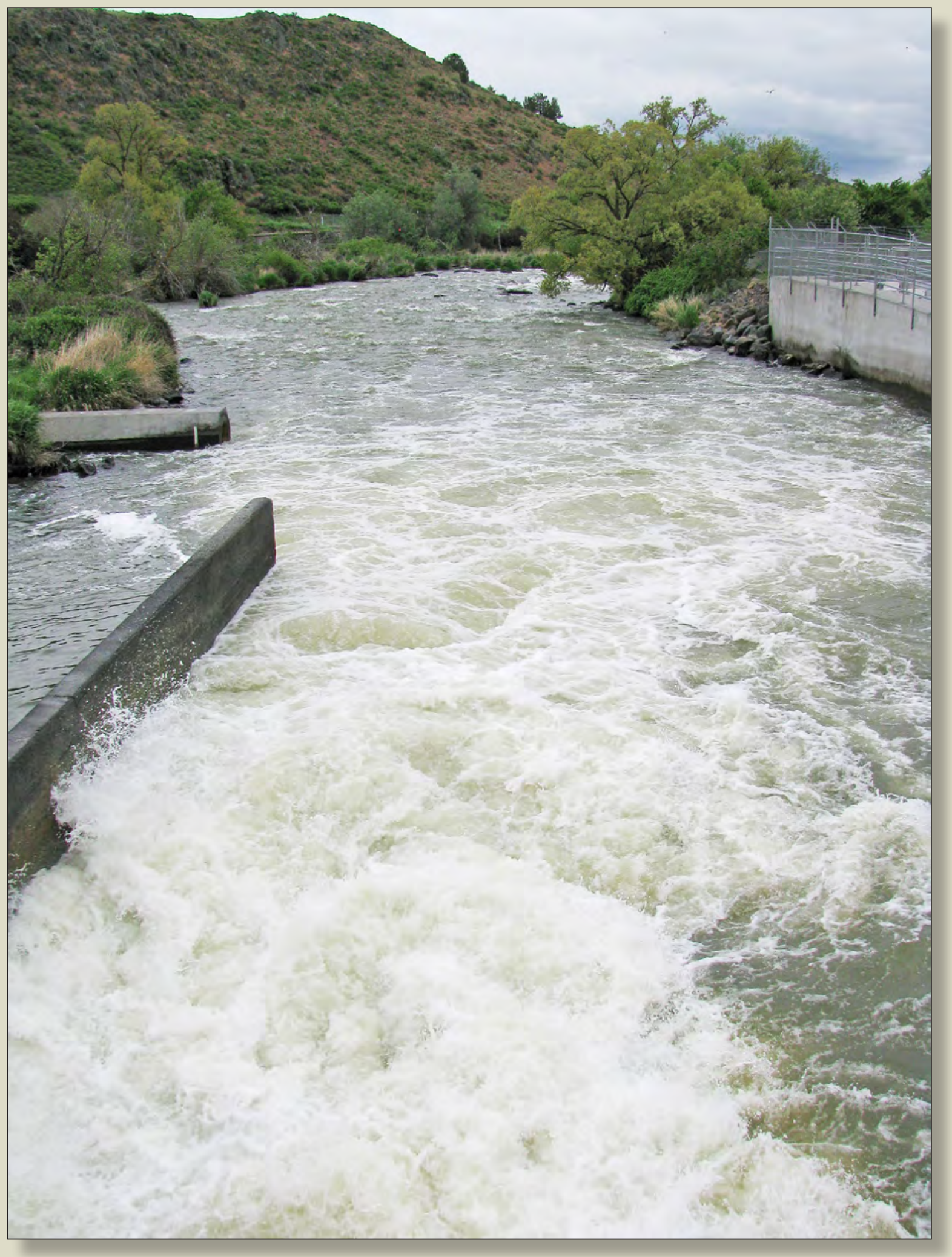

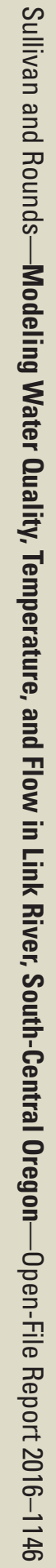

